\title{
PRODUCTION OF BIODIESEL FROM MIXED CASTOR SEED AND MICROALGAL OILS: CHARACTERIZATION AND OPTIMIZATION STUDIES ${ }^{(\mathrm{CA})}$ Dejene Beyene Lemma, Mohammedsani Abdulkadir Abagisa, Adisu Befekadu Kebede Faculty of Civil and Environmental Engineering, Jimma Institute of Technology, Jimma University, Jimma, Ethiopia; P.O.Box: 378, Tel.: +251472115547, Fax: +251471111450 Email: dejenebeyeneaau@gmail.com; mameakadir@ gmail.com; adisu04@gmail.com
}

\begin{abstract}
In order to lower the high prices of individual feedstock, extend the life of a more limited feedstock and to improve the fuel properties of biodiesel it imperative to optimize process parameters for biodiesel derived from mixed feedstocks. Samples of castor seeds were collected from Jimma zone, southwest Ethiopia while sample of wet microalgal biomass was obtained from wastewater stabilization ponds using a 60 um filter screen. The castor seeds and algal biomass were sun-dried before further dried at $80^{\circ} \mathrm{C}$ in an oven and ground to pastes. Oils were extracted from dried and milled castor seeds and micro-algae pastes with a Soxhlet apparatus using methanol. The extracted oil was purified and characterized before converted to biodiesel. A transesterification process designed using Response Surface Methodology (RSM) based on central composite design (CCD) experimental design was used to optimize the biodiesel production process parameters from mixed oil using alkaline catalyst. The Design Expert ${ }^{\circledR} 12$ software was used to analysis experimental results. The effects of catalyst concentration, ethanol to mixed oil molar ratio and reaction temperature on the biodiesel yield were investigated using the experimental results. Accordingly, the optimum conditions for biodiesel production from mixed oil were a catalyst concentration of $1.23 \%$ w.t of the oil, alcohol to mixed oil molar ratio of 5.94:1 (v/v) and reaction temperature of $51.30^{\circ} \mathrm{C}$. The yield of biodiesel under these conditions was 93.88\%. Experiment was conducted under the specified optimum conditions to validate the result predicted by the software. The yield of biodiesel from the experiment was $\mathbf{9 3 . 3 6 \%}$ which is very close to the value predicted by the software. The fatty acid composition of the biodiesel from mixed oil was analyzed using Gas chromatograph. The various fuel properties of biodiesel were determined using standard methods and results were compared with ASTM D6751 and EN 14214 standards. The physicochemical properties fulfill both standards.
\end{abstract}

Keywords: Biodiesel, Castor seed, CCD, Microalgae, Mixed oil, RSM, Transesterification 


\section{INTRODUCTION}

Nowadays, the global community heavily depends on the non-renewable and unsustainable petro-diesel fuel. However, a continued and increasing use of petro-diesel is exacerbating local air pollution and intensifying global warming (Hanna \& Fangrui, 1999). The use of petro-diesel produces primary air pollutants such as nitrogen and sulfur oxides $\left(\mathrm{NO}_{\mathrm{x}}\right.$ and $\left.\mathrm{SO}_{\mathrm{x}}\right)$, carbon monoxide $(\mathrm{CO})$, carbon dioxide $\left(\mathrm{CO}_{2}\right)$, hydrocarbons $(\mathrm{HCs})$ and suspended particulate matter with a serious environmental and health impacts. Nitrogen oxides (NOx) and $\mathrm{HCs}$ react in the atmosphere to form tropospheric ozone that can cause damage to vegetations, building materials and sensitive tissues such as the eyes and lungs. Also $\mathrm{NO}_{\mathrm{x}}$ and $\mathrm{SO}_{\mathrm{x}}$ are the precursors of acid rain which mainly affects aquatic environment and deteriorates material quality (Asmare \& Gabbiye, 2014).

Several studies speculated that if population growth rate and utilization continue at the current rate, fossil fuels will become out of stock within the next few decades. That is why it is highly desirable to find an alternative fuel to petro-diesel. One of the best available alternative fuels in this regard is biodiesel (Atabani et al., 2012). Biodiesel is a biodegradable, non-toxic, carbon neutral, made from local feedstock, used in the current engine technology without significant modifications and similar to petro-diesel in combustion properties (Fajardo et al., 2010) Properties such as high lubricity, flash point and Cetane number also make biodiesel a better fuel over petro-diesel (Lin et al., 2011). Also biodiesel can reduce emissions of $\mathrm{SO}_{\mathrm{x}}$ as it contains no appreciable sulfur (Nwabuokei, 2019).

\subsection{Feedstock for Biodiesel Production}

Throughout the world different feedstocks have been used to produce biodiesel. The feedstock can be divided into four major categories: plant oils, animal fats and oils, algal oil and waste oils (Murugesan et al., 2009). There are many oilseed plants (edible and inedible) that can be used as feedstock of biodiesel. According to (Silitonga et al., 2013) more than 350 oil bearing plants have been identified as a potential feedstock for biodiesel production. A sustainable and economical oilseed plants for biodiesel production must adapt to local conditions, high in oil content, have suitable fatty acid composition, need low agricultural inputs, produce mature seeds at uniform rates and grow in marginal lands unsuitable for cultivating food crops at much lower costs (Banković-Ilić et al., 2012; Moser, 2014). Oils 
from edible oilseed crops such as soybean, sunflower and rapeseed are being used as biodiesel feedstock in developed countries mainly to reduce greenhouse gas emissions and minimize reliance on non-renewable petro-diesel imports (Banković-Ilić et al., 2012). The use of edible oils as feedstock of biodiesel cannot be feasible in Ethiopia and other developing countries because devoting edible oils to biodiesel production compromises food security (Nwabuokei, 2019). In addition, biodiesel made from edible oil sources cannot economically be competitive with petro-diesel (Banković-Ilić et al., 2012). Another reason that necessities the use of non-edible oils for biodiesel production is that non-edible oils are unsuitable for human consumption as they contain some toxic substances. Also growing nonedible oil plants can mitigate climate change by reducing $\mathrm{CO}_{2}$ emissions. Thus, industrial scale production of biodiesel at a reasonable cost needs the use of non-edible oils (BankovićIlić et al., 2012).

Various types of non-edible oil plants have been used for biodiesel production in different parts of the world (Banković-Ilić et al., 2012). Ethiopia is home to diverse varieties of both edible and non-edible oil plants that have an ample potential for biodiesel production. Castor plant (Ricinus communis L.) is an angiosperm that belongs to the family of Euphorbiaceae (Yusuf et al., 2015). The plant is native to Ethiopia though it is also widely distributed throughout the tropical, subtropical and warmer temperate regions (Salihu et al., 2014). Castor plant is resistant to both drought and pest damages and can grow very well on marginal lands unsuitable for crop cultivation (D. Y.C. Leung \& Guo, 2006). The average oil content of all castor seed varieties is about $45-55 \% \mathrm{w} / \mathrm{w}$ though the actual yield depends on climate conditions and oil extraction methods (Banković-Ilić et al., 2012). Nevertheless, castor oil is non-edible and toxic owing to the presence of a toxic protein. Castor oil is unusually polar due to the presence of hydroxyl group at C-12 that accounts for the unique physical and chemical properties such as high viscosity, specific gravity, boiling point and excellent solubility in alcohol (De Lima Da Silva et al., 2009; Yusuf et al., 2015). Castor oil is a triglyceride containing ricinoleic acid (91 - 95\%), linoleic acid (4 - 5\%), oleic acid (2 4\%) and palmitic and stearic acids each 1 - 2\% (Pradhan et al., 2012).

A large variety of waste oils from households and restaurants, food and non-food processing industries can be used as a cheap feedstock for biodiesel production (Banković-Ilić et al., 2012). The use of waste oil instead of virgin oil to produce biodiesel is an effective way to 
handle the cost of biodiesel feedstock. In addition, using waste oils as a feedstock of biodiesel production could solve environmental problems associated with the disposal of such oils (Zhang et al., 2003). However, waste oils contain high free fatty acids, water and many other impurities that require processing before transesterification which make biodiesel production more complicated and costly (Avhad \& Marchetti, 2015; Hassani et al., 2016).

Also animal fats and oils from a variety of animals such as cows, chickens, pigs, fish and insects are potential feedstock for biodiesel production especially in countries with plenty of these resources such as Ethiopia. This feedstock is less expensive than edible oils because it is a by-product not a primary product intended for biodiesel production (D. Y.C. Leung \& Guo, 2006). This makes animal fats and oils an attractive feedstock for biodiesel production (Moser, 2009). Though high saturation makes biodiesel from animal fats and oils an excellent fuel with respect to energy content and Cetane number, poor perform in cold temperatures is a great challenge. Furthermore, high saturation and water content of animal fats and oils make alkaline transesterification a difficult process (Knothe, 2005). Also it has been reported that animal fats and oils may not be plentiful enough to satisfy the current global demands (Atabani et al., 2012; Bhuiya et al., 2016).

Although biodiesel can be made from a variety of feedstocks such as oil bearing plants, waste cooking oils and animal fats and oils, the limited supply of these feedstocks may hinder scaling up biodiesel production to satisfy the current global demands (Johnson, 2009). As the result microalgae have been emerged as one of the most promising feedstock for biodiesel production. Microalgae produce large quantities of oils suitable for biodiesel production (Deng et al., 2009). Fast growth rate, high oil content, ability to grow in areas unsuitable for crop cultivation and low harvesting and transportation costs make microalgae an excellent feedstock for biodiesel production (Chisti, 2007; Deng et al., 2009). Also microalgae never compete with food production as they do not require neither a fertile farmland nor freshwater for cultivation. Microalgae yield more oils per hectare than other feedstocks (Deng et al., 2009). In addition, the use of microalgae as a feedstock of biodiesel can integrate mitigation of greenhouse gases (e.g., $\mathrm{CO}_{2}$ and $\mathrm{NO}_{\mathrm{x}}$ ) from power plants (Chisti, 2007; Park et al., 2010). Microalgae for a large scale biodiesel production can be cultivated in an open or a closed cultivation system (Haldar, 2018). In the open cultivation system, microalgae are not only contaminated by unwanted species but also it is difficult to control growth conditions (e.g., 
temperature and sunlight). However, uncontaminated, large scale microalgae biomass can be cultivated in a closed cultivation system (photobioreactors). Microalgae cultivated in open and closed cultivation systems are usually harvested using centrifugation or flocculation methods (Chisti, 2007; Haldar, 2018).

Besides producing biodiesel from plant oils, animal fats and oils, algae and waste oils, it can be produced from mixed oils to improve the properties of the resulting biodiesel compared to those produced from individual feedstock. The use of mixed feedstocks may lower the cost production of biodiesel. Blending feedstock from different sources may extend the lifetime of the more expensive feedstock (Moser, 2009). The effects of blending various feedstocks may also improve the fuel properties of the resulting biodiesel. Studies have been conducted for mixed oils from canola, palm, soybean and sunflower oils (Moser, 2008). mixed soybean and rapeseed oils (Qiu et al., 2011), mixed mahua and simarouba oils (Jena et al., 2010), palm, rapeseed and soybean oils (Park et al., 2010), jatropha, palm and cottonseed oils (Sarin et al., 2007), Jatropha curcas and Ceiba pentandra oils (Dharma et al., 2016) and mixed castor and soybean oils (Meneghetti et al., 2007). To the best of our knowledge, no study pertaining to the production, characterization and optimization of biodiesel from mixed castor and microalgae oils have been conducted.

\subsection{The Biodiesel Production Process}

Although different techniques like blending, microemulsions and pyrolysis can be used to produce biodiesel, transesterification is the most commonly used process to lower the viscosity of the feedstock (Banković-Ilić et al., 2012). Transesterification also called alcoholysis is either non-catalyzed or catalyzed reaction in which a triglyceride and an alcohol react to produce fatty acid alkyl esters (FAAE) or glycerol. In biodiesel production, catalysts are required to improve reaction rates and yields (Hanna \& Fangrui, 1999). Transesterification reaction can be catalyzed by alkaline (basic) catalysts (e.g., $\mathrm{NaOH}, \mathrm{KOH}$, carbonates and their corresponding alkoxides), acid catalysts (e.g., sulfuric acid, boron trifluoride, phosphoric acid, sulfonic acids and hydrochloric acid) or enzyme catalysts (e.g., lipases) (Demirbas, 2005). Catalyzed transesterification reactions can be accomplished as one-step (basic or acidic) or two-step (acidic/basic) processes depending on the free fatty acid content of the feedstock. Based on the solubility of the catalyst in the reaction mixture, 
transesterification can be catalyzed by homogeneous or heterogeneous catalysts (BankovićIlić et al., 2012).

Homogenous base catalyzed transesterification is much faster, less expensive and more complete than the corresponding acid-catalyzed transesterification (Moser, 2009). According to (Srivastava \& Prasad, 2000) alkali-catalyzed transesterification is about 4,000 times faster than the corresponding acid catalyzed transesterification. However, alkali-catalyzed transesterification is very sensitive to water and free fatty acid contents of the feedstock (Banković-Ilić et al., 2012). Under alkaline conditions the presence of excess water may trigger saponification (soap formation). Also if present in sufficient amount, free fatty acid reacts with alkaline catalysts to produce soaps and water (Moser, 2009). Saponification not only increases the cost of biodiesel production by consuming more catalysts but also the produced soap can form emulsion which makes the purification of biodiesel a more difficult process (Abidin, 2012).

On the other hand homogenous acid-catalyzed transesterification reaction is insensitive to free fatty acid contents of the feeddstock due to their ability to simultaneously catalyze both esterification and transesterification reactions (Banković-Ilić et al., 2012). However, the reaction rate is slower, corrosive to equipment, occurs at higher temperatures and pressure and requires longer reaction time, a lower catalyst activity and a higher alcohol to oil molar ratio to achieve a significant yield of biodiesel (Babajide et al., 2011; Banković-Ilić et al., 2012). Enzyme catalyzed transesterification reaction is carried out in non-aqueous environments organic and ionic liquids, gaseous media and supercritical fluids (Babajide et al., 2011; Banković-Ilić et al., 2012). According to (Abidin, 2012) enzyme-catalyzed transesterification reaction generates no by-products, produce high yield under mild conditions, insensitive to FFA and water contents of the feedstock, simultaneously catalysis transesterification and esterification reactions and product separation and catalyst recovery are too easy. However, enzyme-catalyzed transesterification requires a longer reaction time than the corresponding alkali and acid catalyzed transesterifications (Moser, 2009). Furthermore, high costs and deactivation of the enzyme pertaining to impurities are the major hindrance to the use of enzyme-catalyzed transesterification (Babajide et al., 2011). Biodiesel can also be produced via non-catalytic supercritical fluid transesterification processes. This method is less expensive and produces high yield of biodiesel because both 
transesterification and esterification reactions occur simultaneously in a single step (Demirbas, 2005).

In heterogeneous catalyzed transesterification reaction the yield of biodiesel is also influenced by reaction conditions. It requires higher alcohol to oil ratio, catalyst concentration and reaction temperature and much longer reaction time compared to homogeneous catalyst transesterification to achieve comparable biodiesel yield. However, optimal reaction conditions must be determined experimentally to obtain a better yield. The type of a heterogeneous catalyst depends on the free fatty acid contents of the feedstock. Basic heterogeneous catalysts are preferable if the free fatty acid content of the feedstock is lower. On the other hand feedstock with higher free fatty acid content must employ acidic heterogeneous catalyst because acid solid catalysts can simultaneously catalyze esterification and transesterification reaction in one single step, lowering reaction time and energy consumption. A mixture of acidic and basic heterogeneous catalysts with a better catalytic activity has been produced by impregnation and co-precipitation techniques for a simultaneous esterification and transesterification process (Banković-Ilić et al., 2012).

Short chains anhydrous alcohols such as methanol, ethanol, propanol, butanol and amyl alcohols are commonly used during transesterification to produce biodiesel. However, methanol is the most frequently used alcohol mainly due to its lower cost, better yields, fast reaction time and suitable physical and chemical properties (Zhang et al., 2003).

\subsection{Main Factors affecting the Yield of Biodiesel}

The quality of feedstock largely determines the type of catalyst or process used to produce a biodiesel of good quality (Moser, 2009). According to (Banković-Ilić et al., 2012), alcohol to oil molar ratio, catalyst type and concentration, reaction time and temperature, mixing speed and free fatty acid and water contents of feedstock are the most important factors that influence the yield of biodiesel.

Several studies show that one of the main factors that influence the yield of biodiesel is alcohol to oil molar ratio. Stoichiometrically transesterification requires 3 moles of alcohol and 1 mole of triglyceride to yield 3 moles of fatty acid alkyl ester (biodiesel) and 1 mole of glycerol (Banković-Ilić et al., 2012; Chisti, 2007; Srivastava \& Prasad, 2000). However, an excess alcohol must be used to shift the equilibrium to the product side. Raising alcohol to oil molar ratio beyond 3:1 increases the yield of biodiesel until optimum point is reached. This is 
because a higher alcohol to oil molar ratio can result in a greater ester conversion within a shorter reaction time (Srivastava \& Prasad, 2000). However, increasing the ratio further beyond the optimum increases the cost for alcohol recovery from the reaction medium. Furthermore, the molar ratio of alcohol to oil or fat depends on the type of catalyst used and most studies show that the optimal molar ratio for an alkali catalyst is 6:1 (Zhang et al., 2003). If the oils or fats contain higher percentage of free fatty acids (FFA), a molar ratio as high as 15:1 is required for acid-catalyzed transesterification (Dennis Y.C. Leung et al., 2010).

The oil or fat, catalyst and alcohol used in alkaline catalyzed transesterification must be anhydrous i.e. water content must less than $0.05 \mathrm{w} / \mathrm{w} \%$ in order to prevent loss of biodiesel yield due to soap formation (Chisti, 2007). Another factor that influences the yield of biodiesel is type and concentration of catalyst. If the feedstock contains a significant amount of free fatty acids ( $\geq 3 \mathrm{w} / \mathrm{w} \%$ ), typical homogenous alkaline catalysts such as $\mathrm{NaOH}$ or $\mathrm{KOH}$ will not be effective because these catalysts react with FFA to form soap and water (Dennis Y.C. Leung et al., 2010; Moser, 2009). For an optimal biodiesel yield using a homogenous alkaline catalyst, the free fatty acid content of the feedstock must be less than $0.05 \mathrm{w} / \mathrm{w} \%$ (Hanna \& Fangrui, 1999). For feedstock containing FFA $\geq 1 \mathrm{w} / \mathrm{w} \%$, transesterification with homogenous alkaline catalysts must be preceded with an acid pretreatment (Wang et al., 2005). At low catalyst concentration the low conversion rate of triglyceride can lead to low biodiesel yield. This is because insufficient amount of catalysts result in an incomplete conversion of feedstock to biodiesel (Dennis Y.C. Leung et al., 2010) The yield usually reaches an optimal level when the catalyst concentration reaches $1.5 \mathrm{w} / \mathrm{w}$ $\%$ and then decreases with a further increase in catalyst concentration because excess alkali catalyst causes more oil or fat to react with alkali catalyst to form more soap (Eevera et al., 2009; Dennis Y.C. Leung et al., 2010). Thus, further increase in catalyst concentration encores additional costs associated to catalyst removal from the reaction medium without increasing the yield of biodiesel (Srivastava \& Prasad, 2000).

Types of catalyst also affect the transesterification reaction and thus the yield of biodiesel. Sodium hydroxide $(\mathrm{NaOH})$ is the most commonly used homogenous alkaline catalyst. However, sodium methoxide is more effective than $\mathrm{NaOH}$ because mixing $\mathrm{NaOH}$ and alcohol forms water, which affects the yield of biodiesel (Moser, 2009). This is why we need 
to add catalyst to alcohol first and then alkoxide (a mixture of alcohol and catalyst) is mixed with the fats or oil during transesterification process (Knothe, 2005).

Temperature also influences the rate of transesterification and yield of biodiesel (Dennis Y.C. Leung et al., 2010). A higher temperature can lower the viscosities of oils, increases reaction rate and shortens reaction time but increasing reaction temperature beyond the optimal level lowers yield of biodiesel because a higher temperature accelerates the saponification reaction (Banković-Ilić et al., 2012; Eevera et al., 2009; D. Y.C. Leung \& Guo, 2006). In order to avoid loss of alcohol via vaporization, the reaction temperature must be less than the boiling point of the alcohol used for transesterification process. Optimal temperature for transesterification reaction ranges from 60 to $80{ }^{\circ} \mathrm{C}$ based on the alcohol used for the process (Freedman B et al., 1984; Hanna \& Fangrui, 1999; Leung \& Guo, 2006).

According to (Freedman et al., 1984) the conversion rate of fats or oils increases with increase in reaction time. At the start, the reaction is slow because mixing and dispersion of alcohol with the oil or fat need time. Then the reaction proceeds very fast. Once the yield reaches a maximum at an optimal reaction time, a further increase in the reaction time will not change the yield (Dennis Y.C. Leung et al., 2010) Alkaline catalyzed transesterification reactions are basically complete within one hour (Moser, 2009). However, reaction time beyond optimum level reduces yield of biodiesel due to the reverse of transesterification reaction and more oils or fats are used to produce soaps (Dennis Y.C. Leung et al., 2010)

\section{MATERIALS AND METHODS}

\subsection{Sample Collection and Preparation}

The wet micro-algal biomass was collected from Wastewater Stabilization Ponds (WWSPs) at Jimma Institute of Technology, Southwest Ethiopia, using a $60 \mu \mathrm{m}$ filter screen. Nearly 24 $\mathrm{kg}$ wet micro-algal biomass was collected and concentrated by centrifugation. A total of 8.56 $\mathrm{kg}$ of wet microalgae biomass was obtained during the whole harvesting time. The microalgal biomass was dried using a freeze drier and weighed. The dried micro-algae biomass was then milled to a paste using a mortar and pestle. The powdered microalgal paste was stored in plastic bag until used for oil extraction. On the other hand, castor seeds were collected from Jimma zone Dedo District and transported to Jimma University where they undergone various preparation steps including manual removal of foreign materials and seed 
shells, oven drying at $105^{\circ} \mathrm{C}$ for 6 hours to get rid of excess moisture and grinding into a powder using a mortar and pestle to weaken cell walls for efficient oil extraction.
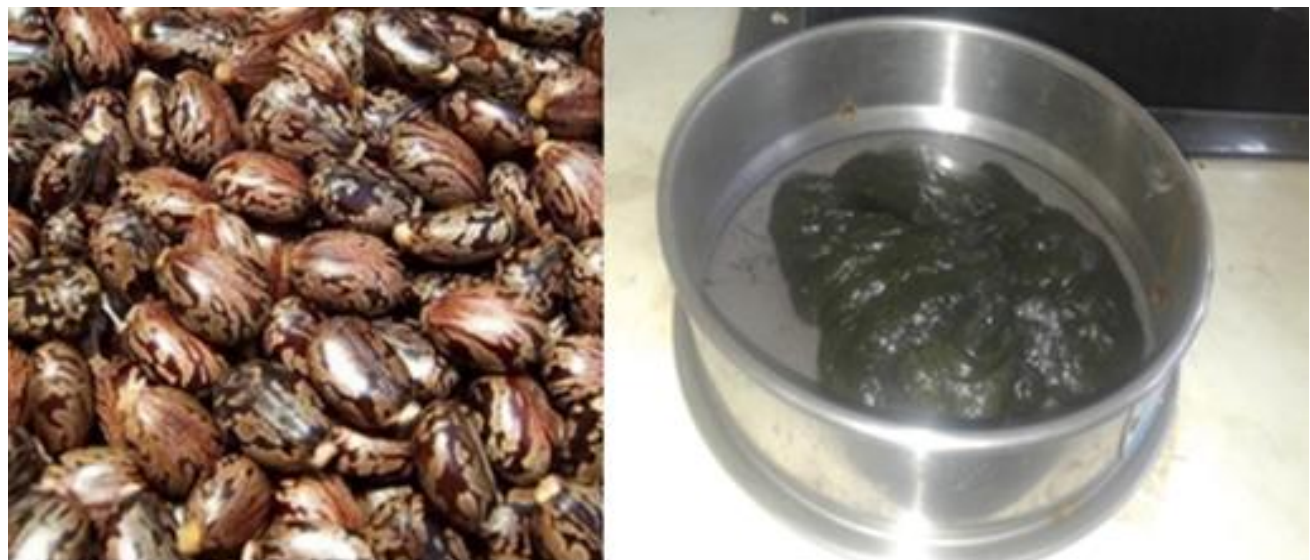

Fig. 1: Samples of raw castor seeds and microalgae biomass used for oil extraction

The dried castor seeds then cooled to room temperature in a desiccator and re-weighed to determine the loss of weight to determine (\%) moisture content using the following expression (Eqn. 1):

Moisture content, $\%=\frac{\text { Weght Before Drying }- \text { Weght After Drying }}{\text { Weght Before Drying }} \times 100$

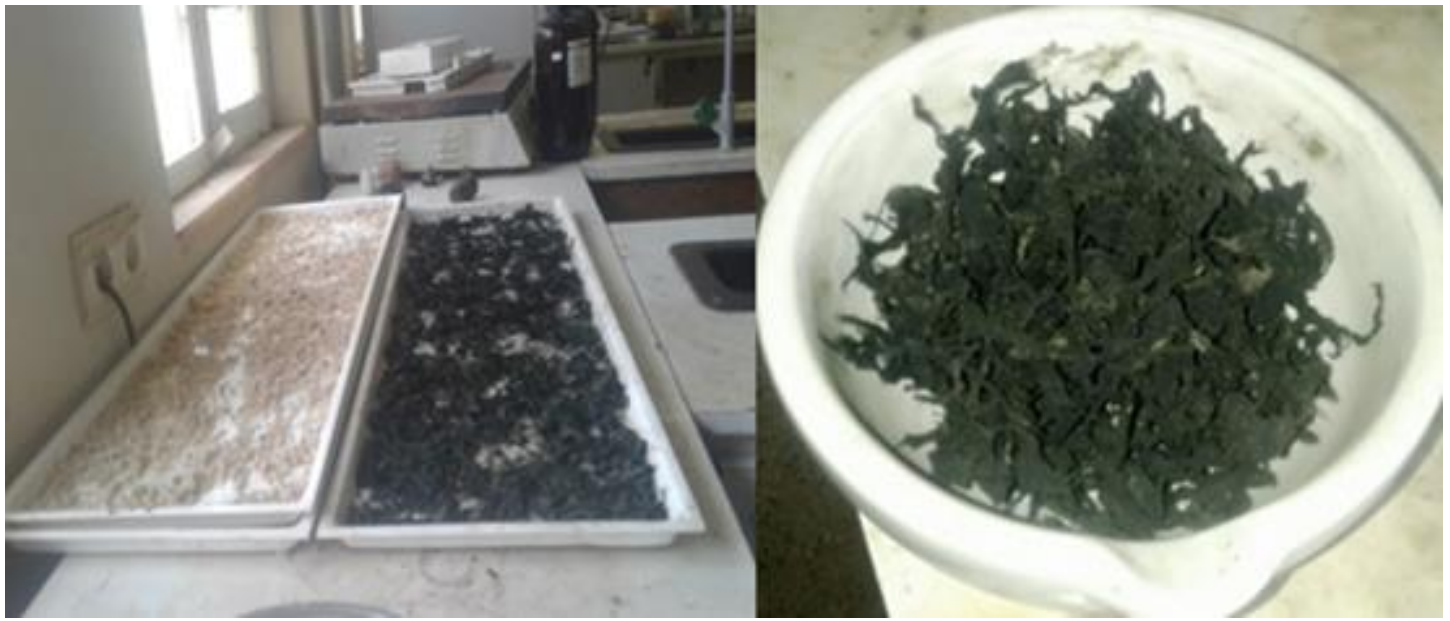

Fig. 2: Preparation of microalgal past

The amount of oil in the raw material (both algae and castor seed) was determined using the following expression (Eqn. 2):

$\%$ of oil yield $=\frac{\text { Weight of oil obtained }}{\text { Weight of sample used for oil extraction }} \times 100 \%$

Several materials and basic equipment were used during the field work and experimental processes including oven, Soxhlet apparatus, desiccator, centrifuge, digital balance, digital $\mathrm{pH}$ meter, mortar and pestle, burrrets, hot plate fitted with temperature prone and magnetic 
stirrer, Densimeter, Viscometer, Pensky-Martens closed cup tester, beakers and flasks, hydrometer, micro-filter screen, freeze drier, glass bottles, condenser, furnace, rotary evaporator, refrigerator and GC. All experiments were conducted in triplicate using analytical grade chemicals and solvents obtained from Jimma University Laboratory and a local vendor. N-hexane $(99 \% \mathrm{w} / \mathrm{w})$, methanol $(99 \% \mathrm{w} / \mathrm{w})$, ethanol $(99.5 \% \mathrm{w} / \mathrm{w})$, potassium hydroxide (95\%), sodium hydroxide (anhydrous with 98\% purity), phosphoric acid (98\% w/w), hydrochloric acid (98\% w/w), sulphuric acid (98\%), potassium iodide (anhydrous with $98 \%$ purity), phenolphthalein indicator (analytical grade), starch solution, chloroform, hanus solution, sodium sulfate (anhydrous) and sodium thiosulfate were some of the chemicals used during the study.

\subsection{Oil Extraction and Purification}

The pre-treated and prepared micro-algal and castor seed pastes were used for oil extraction with Soxhlet apparatus using methanol as a solvent. Methanol was poured into a round bottom flask. The castor seed paste was weighed and inserted into the center of extractor. The Soxhlet was heated at $60^{\circ} \mathrm{C}$ and oil extraction was carried out for 1 hour. At the end of reaction time the castor seed paste was removed from Soxhlet, dried in an oven at $105^{\circ} \mathrm{C}$, cooled in a desiccator and weighed again to determine the amount of oil extracted. At the end of one hour, the mixture was placed in a separatory funnel and allowed to stand for 24 hours to ensure the complete separation of oil and solid impurities.

The extracted oil was filtered through a sieve and heated to a temperature of $120^{\circ} \mathrm{C}$ for 30 minutes to remove water and residual solvents. The extracted oil was then washed repeatedly with warm distilled water until it becomes neutral and as clear as it was before used for washing. One liter of oil mixture was poured into a $2000 \mathrm{ml}$ beaker, heated to $60^{\circ} \mathrm{C}$ and then $1 \% \mathrm{v} / \mathrm{v} \mathrm{H}_{3} \mathrm{PO}_{4}$ was added and mixed thoroughly. The mixture was maintained at $60^{\circ} \mathrm{C}$ for 1 hour and $100 \mathrm{ml}$ hot water was added and mixed thoroughly. The mixture was transferred to a separator funnel where it was separated into oil and heavy sludge layers (Fig. 3). The sludge layer containing phosphatides, pigments and other impurities was separated and discarded. Then the refined oil was weighed and stored in an amber glass bottle until used for biodiesel production.

Once the free fatty acid (FFA) content of the oil was known, oil sample was neutralized by a $0.50 \mathrm{~N} \mathrm{NaOH}$. A 0.86 gram of $\mathrm{NaOH}$ was used per $100 \mathrm{ml}$ of oil sample to neutralize and 
coagulate the FFA of the oils extracted from microalgae and castor seeds. Accordingly $0.50 \mathrm{~N}$ $\mathrm{NaOH}$ was added to oil at $70^{\circ} \mathrm{C}$ and then stirred at $200 \mathrm{rpm}$ for one hour to neutralize the FFA in the oil. The coagulated FFA was centrifuged at $800 \mathrm{rpm}$ for 20 minutes to separate solid materials. Later the mixture was washed with distilled water to remove a trace $\mathrm{NaOH}$. Finally, the oil was oven dried at $105^{\circ} \mathrm{C}$ for one hour to remove trace water. This process brought the free fatty acid content of the oil to less than $0.50 \%$ which makes the oil suitable for biodiesel production via transesterification using an alkaline catalyst.

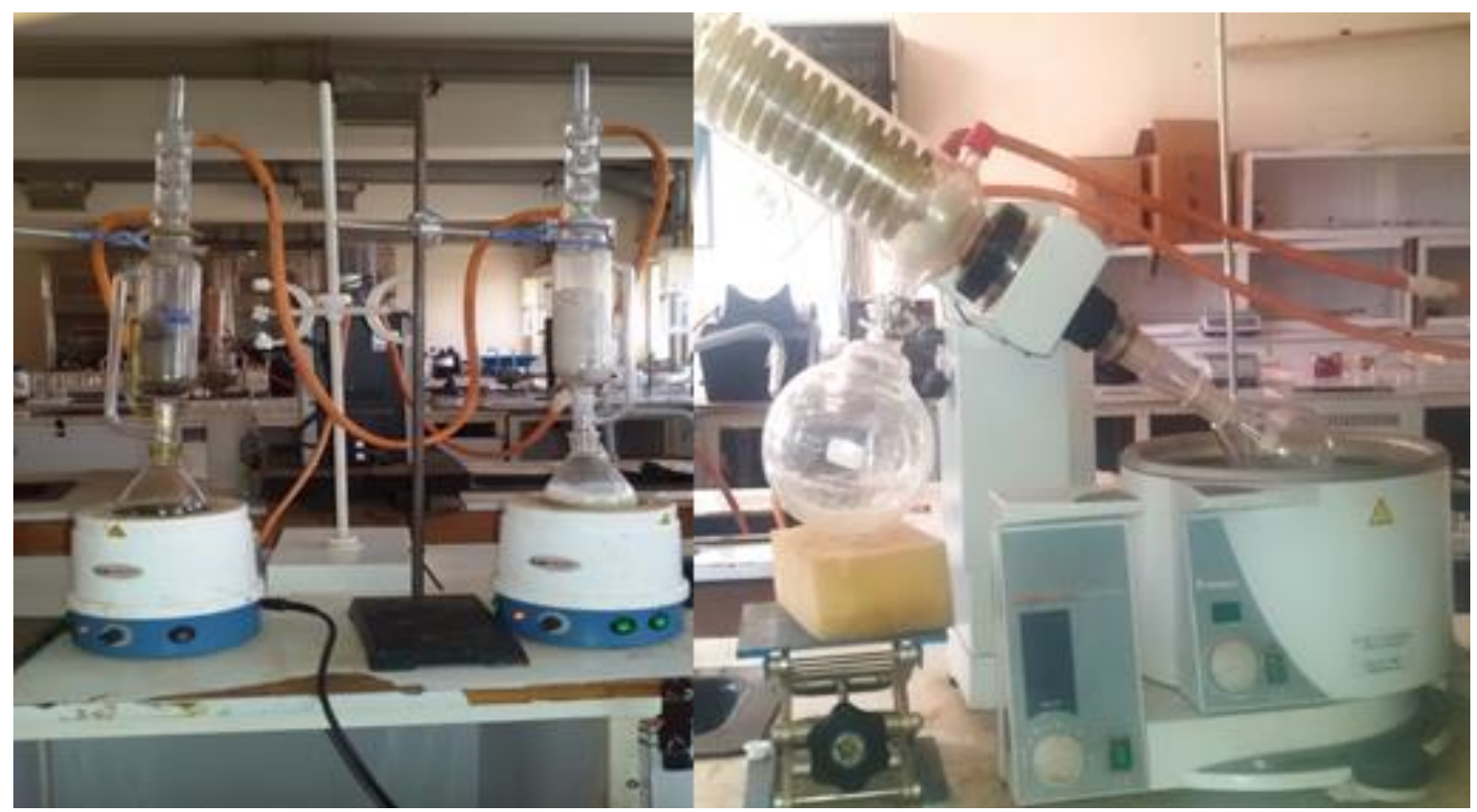

Fig. 3: Soxlet apparatus and Rotary evaporator setup for oil extraction and purification

\subsection{Physicochemical Characteristics of Mixed Oil and Biodiesel}

Before converting the extracted mixed oil (1:1 ratio) into biodiesel by transesterification process it was very important to characterize the oil to know the amount of pre-treatment needed. Properties such as moisture content, saponification value, acid value, kinematic viscosity, specific gravity, density, free fatty acid value, fatty acid composition and ash content of the mixed oil were determined to ensure that the oil fulfills the requirements for transesterification using an alkaline catalyst. On the other hand biodiesel produced from the mixed oil undergone different laboratory tests to determine its fuel properties and qualities. The test results were compared with European Union Biodiesel Quality Standard (EN14214) and American Society for Testing and Materials (ASTM D6751) specifications. 


\subsubsection{Moisture Content of the Mixed Oil and Biodiesel}

Before transesterification, water removal from oil is necessary because high water content facilitates side reactions (Hanna \& Fangrui, 1999). Water content in excess of $0.050 \mathrm{w} / \mathrm{w} \%$ can lower yield of biodiesel through hydrolysis of FFAs and by causing transesterification reaction to form soap. The soap produced also makes the separation of biodiesel and glycerol difficult (Banković-Ilić et al., 2012). A higher water and free fatty acid contents urges acid catalyzed transesterification to produce biodiesel (Moser, 2009). In this study, the water content of mixed oil and biodiesel was determined using the oven drying method. The preweighed mixed oil and biodiesel samples were dried in an oven at $10^{\circ} \mathrm{C}$ for one hour. The samples were weighed again after drying and the moisture content was determined using the following expression:

MC $(\%)=\frac{\text { Weight before drying }- \text { Weght after drying }}{\text { Weght before drying }} \times 100$

\subsubsection{Acid Value (AV) and Free Fatty Acid (FFA) value of Mixed Oil and Biodiesel}

The acid value is used to quantify the amount of acid present in a sample of oil and biodiesel (Hanna \& Fangrui, 1999). Acid value (AV) of the feedstock has a significant effect on the transesterification reactions if an alkaline catalyst is to be used (Indhumathi et al., 2014). It is the quantity of a base (expressed in milligrams of $\mathrm{KOH}$ ) required to neutralize the acid constituents in one gram of a sample (Taghizade, 2016). To determine the acid value of the mixed oil, the oil sample was placed in a laboratory flask. An ethanol with $99.5 \% \mathrm{w} / \mathrm{w}$ purity was added to the sample and the mixture was boiled using a temperature controlled water bath. After cooling to room temperature, 2 drops of phenolphthalein indicator was added to the mixture. Then the mixture was titrated with $0.10 \mathrm{~N} \mathrm{KOH} \mathrm{(Fig.} \mathrm{4).} \mathrm{The} \mathrm{acid} \mathrm{value} \mathrm{of} \mathrm{the}$ mixed oil was estimated using the following expression:

$\mathrm{AV}(\%)=\frac{\mathrm{C} \times \mathrm{V} \times 56.1}{\text { Weight of oil sample }(g)} \times 100$

Where $\mathrm{V}$ is volume of $\mathrm{KOH}$ used for titration and 56.10 is molecular weight of $\mathrm{KOH}$

The mixture was washed with a distilled water to remove trace $\mathrm{KOH}$ and produced soap. The free fatty acids were neutralized using $0.05 \mathrm{~N}$ of $\mathrm{KOH}$. The free fatty acid (FFA) value of mixed oil and biodiesel is half of acid value (Taghizade, 2016). The free fatty acid value was calculated using the following expression: 
$\mathrm{FFA}=\frac{\mathrm{AV}}{2}$

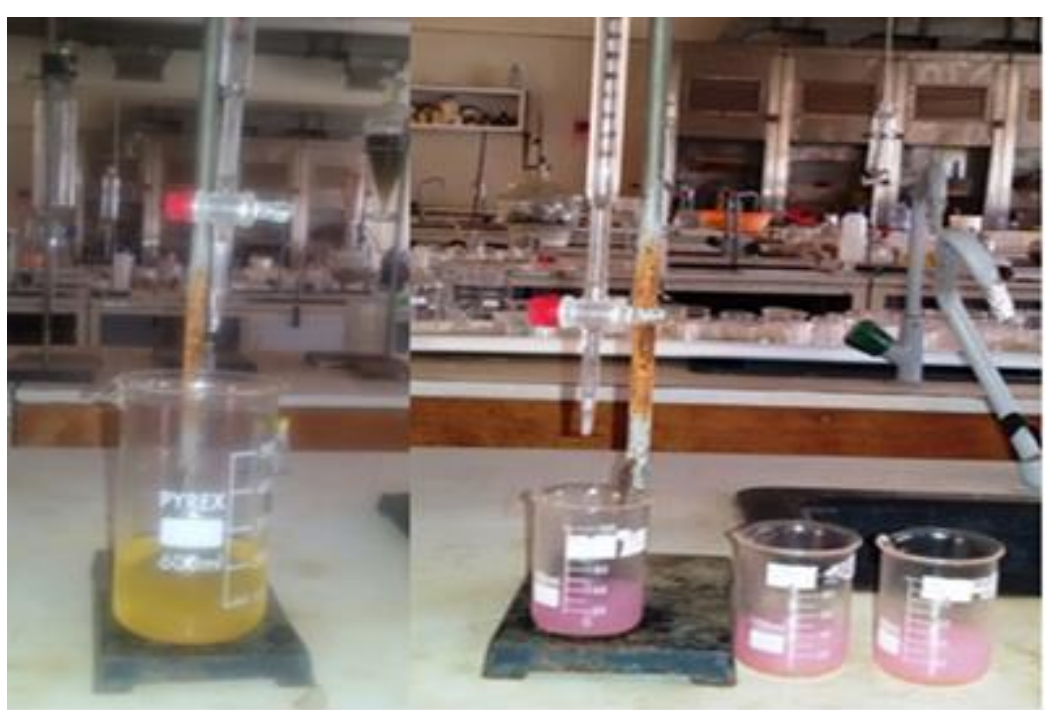

Fig. 4: Determinations of acid value of mixed oil and biodiesel samples by titration method

\subsubsection{Saponification Value (SV) of Mixed Oil and Biodiesel}

Saponification value is the amount of alkaline catalysts $(\mathrm{NaOH}$ or $\mathrm{KOH})$ required to saponify 1 gram of triglyceride under specific conditions (Babajide et al., 2011). It is a measure of the chain length of all the fatty acids present in the feedstock. Two gram oil sample was added to a conical flask containing a $0.50 \mathrm{~mol} / \mathrm{L} \mathrm{KOH}$ solution in anhydrous ethanol $(99.5 \% \mathrm{w} / \mathrm{w})$ and heated to $70^{\circ} \mathrm{C}$ for 30 minutes. A few drops of phenophtaline indicator were added to the mixture after cooling. The excess $\mathrm{KOH}$ was titrated against $0.50 \mathrm{~mol} / \mathrm{L} \mathrm{HCl}$ solution using a phenolphthalein indicator until the endpoint was reached and the volume of $\mathrm{HCl}$ needed to bring color change was recorded. A blank (without oil sample) was saponified by the same procedure. Then the saponification value of the mixed oil was determined using the following expression:

$\mathrm{SV}=\frac{\left(B_{1}-B_{2}\right) \times C \times 56.1}{\mathrm{M}(g)}$

Where $\mathrm{SV}$ is saponification value, $\mathrm{B}_{1}$ and $\mathrm{B}_{2}$ are the volumes of $\mathrm{HCl}$ used for blank fatty acid and oil mixture titrations respectively, $\mathrm{C}$ is the concentration of $\mathrm{HCl}(\mathrm{mol} / \mathrm{L}), M$ is weight of oil (g) and 56.1 is molecular weight of $\mathrm{KOH}$. The same procedure was used to determine the SV of biodiesel. 


\subsubsection{Density of the Mixed Oil and Biodiesel}

The specific gravity or relative density of the mixed oil was determined by taking the ratio of the mass of $50 \mathrm{ml}$ oil mixture at $20^{\circ} \mathrm{C}$ to the mass of an equal volume of water at the same temperature $\left(20^{\circ} \mathrm{C}\right)$ according to the following expression):

$$
S_{g}=\frac{\mathrm{M}_{o} \text { at } 20^{\circ} \mathrm{C}}{\mathrm{M}_{w} \text { at } 20^{\circ} \mathrm{C}}
$$

Where

$$
\begin{aligned}
& \mathrm{Sg}=\text { specific gravity, unitless } \\
& \mathrm{Mo}=\text { mass of } 50 \mathrm{ml} \text { of oil at } 20^{\circ} \mathrm{C} \\
& \mathrm{Mw}=\text { mass of } 50 \mathrm{ml} \text { of water at } 20{ }^{\circ} \mathrm{C}
\end{aligned}
$$

The density of mixed oil was determined by multiplying specific gravity of mixed oil by density of water $\left(1000 \mathrm{~kg} / \mathrm{m}^{3}\right)$. On the other hand, the density of the biodiesel sample at $15^{\circ} \mathrm{C}$ was determined using a hydrometer. A $100 \mathrm{ml}$ biodiesel sample was heated to $15^{\circ} \mathrm{C}$ and filled into graduate cylinder. The hydrometer was inserted into the graduated cylinder with biodiesel sample to measure its density. Reading was taken after the hydrometer becomes stabilized.

\subsubsection{Kinematic Viscosity of Mixed Oil and Biodiesel}

A digital Vibro Viscometer (SV-10, Australia) was used to determine the viscosity of the mixed oil. The oil sample filled in the viscometer cup was kept in a water bath at $40^{\circ} \mathrm{C}$ for 30 minutes. Then the Viscometer tip was inserted into the viscometer cup containing the oil sample and reading was taken for a fixed volume. The reading of the Viscometer is dynamic viscosity that was corrected to find the kinematic viscosity using the following expression:

Kinematic Viscosity $(v)=\frac{\text { Dynamic viscosity }(\eta)}{\text { Density of sample }(\rho)}$

The kinematic viscosity was determined by determining the flow time for a volume of biodiesel to pass between two marked points on the instrument placed in an upright position (Hurtado et al., 2019)In this study, the viscosity of the biodiesel was determined using Ostwald-Cannon-Fenske capillary Viscometer (Viscometer-33200). From the flow time required to pass between two marked points (in seconds), kinematic viscosity (in centistokes) was calculated using the following expression:

Kinematic viscosity $(v)=C^{*} \mathrm{t}$ 
Where $\mathrm{C}$ is the calibration constant for the instrument $\left(\mathrm{mm}^{2} / \mathrm{s}^{2}\right)$ specified by manufacturer $\left(0.040350 \mathrm{~mm}^{2} / \mathrm{s}^{2}\right.$ in this case $)$ and $t$ is time required to pass between two marked points (seconds). All measurements were carried in triplicate and only the average value was used in the final report provided variations would not exceed $0.35 \%$ (Hurtado et al., 2019).

\subsubsection{Iodine Value (IV) of Biodiesel}

Iodine value specifies the amount of iodine ( $\mathrm{g}$ ) consumed by $100 \mathrm{~g}$ of a biodiesel sample. A higher IV indicates the biodiesel contains more unsaturated fatty acids ( $\mathrm{C}=\mathrm{C}$ bonds). In this study, iodine value was determined by placing $0.10 \mathrm{~g}$ of the biodiesel sample in a $250 \mathrm{ml}$ Erlenmeyer flask, adding $10 \mathrm{ml}$ of anhydrous chloroform followed by addition of $30 \mathrm{ml}$ of Hanus solution (Fig. 5). The content was mixed and placed in a dark for 30 minutes. At the end of 30 minutes, $10 \mathrm{ml}$ of $15 \% \mathrm{w} / \mathrm{v}$ of potassium iodide solution was added to the flask to wash down any iodide remain on the stopper. The entire content was then titrated against $0.140 \mathrm{M} \mathrm{Na}_{2} \mathrm{~S}_{2} \mathrm{O}_{3}$ until the solution turned light yellow. After adding $2 \mathrm{ml}$ of $1 \%$ starch solution, titration was continued until the blue colour disappears. The blank titration was carried out without oil sample. Finally iodine value of the biodiesel was estimated using the following expression:

$\mathrm{IV}=\frac{\left(B_{2}-R_{2}\right) * N * 12.69}{M(g)}$

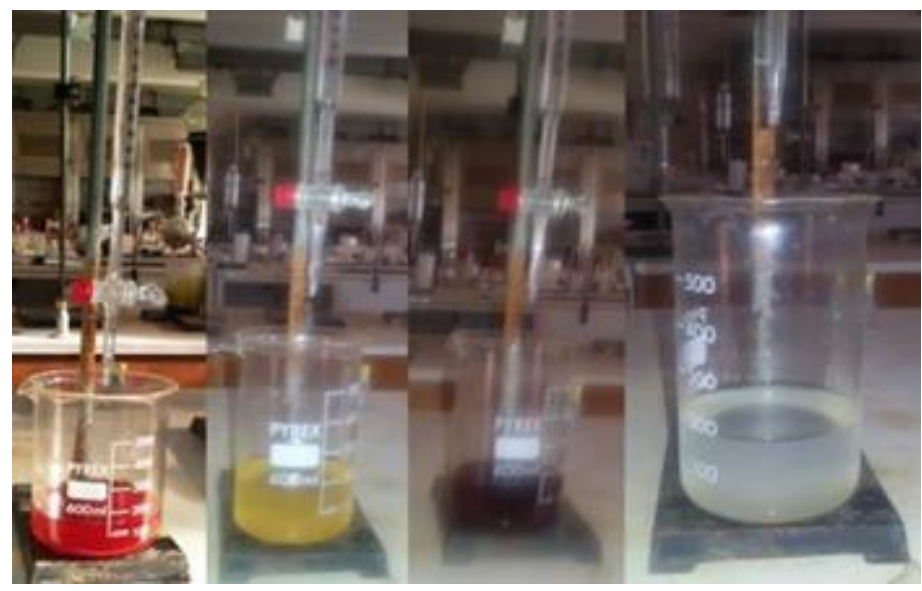

Fig. 5: Determination of Iodine value by titration method

Where IV is iodine value ( $\mathrm{g}_{2} / 100 \mathrm{~g}$ biodiesel), $\mathrm{M}$ is mass of biodiesel used $(\mathrm{g}), \mathrm{N}$ is normality of sodium thiosulfate $\left(\mathrm{Na}_{2} \mathrm{~S}_{2} \mathrm{O}_{3}\right)$ and $\mathrm{B}_{2}$ and $\mathrm{R}_{2}$ are the volume of $\mathrm{Na}_{2} \mathrm{~S}_{2} \mathrm{O}_{3}$ used for blank and sample titration respectively. The same procedure was used to determine iodine value of oil mixture before transesterification. 


\subsubsection{Cetane Number $(\mathrm{CN})$ of Biodiesel}

In this study, CN value of the biodiesel was estimated using the results of SV and IV according to the following expression: (Nascimento et al., 2013; Obianke et al., 2018).

$\mathrm{CN}=46.3+\frac{5458}{\mathrm{SV}}-0.225 * \mathrm{IV}$

Where $\mathrm{CN}$ is Cetane number

\subsubsection{Heating Value (HV) of Biodiesel}

Numerous mathematical models have been formulated to estimate the heating value for vegetable oils and biodiesel synthesized from them based on data from physical or chemical compositions, proximate or ultimate analysis and structural analysis of vegetable oils and biodiesel synthesized from them (Sanli et al., 2014). In this study, an empirical formula suggested by (Demirbaş, 1998; Demirbas et al., 2018) is used to estimate the heating value (calorific value) of the mixed oil and biodiesel made from it as a function of its iodine value (IV) and saponification value (SV) according to the following expression:

$\mathrm{HHV}(\mathrm{MJ} / \mathrm{kg})=49.43-(0.041 \mathrm{xSV})-(0.015 \mathrm{xIV})$

\subsubsection{Flash point of Biodiesel}

In this study, Pensky-Martens Closed Cup Tester was used to measure the flash point of biodiesel sample. The cup was filled with sample of biodiesel, heated with an external heater while being stirred. A small open flame was maintained via external supply of natural gas. The stirrer was stopped periodically and the flame pivoted down to check if the biodiesel vapor ignites. The temperature at which a small flash observed was recorded as observed flash point of the biodiesel and then corrected to atmospheric pressure $(760 \mathrm{mmHg}$ ) by applying the correction factor, according to the following expression:

$\mathrm{FP}($ Corrected $)=\mathrm{T}\left({ }^{\circ} \mathrm{C}\right)+0.033(760-\mathrm{P})$

Where FP is flash point of the biodiesel; $\mathrm{T}$ is observed temperature $\left({ }^{\circ} \mathrm{C}\right) ; \mathrm{P}$ is atmospheric pressure $(\mathrm{mmHg})$ prevailing at the time of test.

\subsubsection{Ash Content (AC) of Mixed Oil and Biodiesel}

Furnace was used to determine the ash content of the oil. A burning cup containing $20 \mathrm{~g}$ oil was placed in a furnace for 4 hour which was set at a temperature of $550^{\circ} \mathrm{C}$. Then after burning the residue remaining was weighted and ash content was determined using following expression: 
$\mathrm{AC}(\%)=\frac{M_{2}}{M_{1}} * 100$

Where $\mathrm{AC}$ is ash content (\%); $\mathrm{M}_{1}$ is mass of oil before burning; $\mathrm{M}_{2}$ is mass of oil after burning

\subsubsection{Fatty Acid and ethyl ester Composition of Mixed Oil and Biodiesel}

Fatty acid composition of sample of mixed oil and biodiesel was identified by GC method. Into a flask, a sample of mixed oil and n-hexane were added and shaken and stands idle for one minute. An anhydrous sodium sulfate was used to dry the solution. After shaking, the solution was let stand idle for 5 minutes until sedimentation occurs. The solution was analyzed using GC (CP-3380) equipped with a flame ionization detector with a Supelcowax 10 capillary column, $30 \mathrm{~m} \times 0.25 \mathrm{~mm} \times 0.25 \mu \mathrm{m}$. The injector temperature was set at $250^{\circ} \mathrm{C}$. The column temperature was programmed to increase from $50^{\circ} \mathrm{C}$ to $250^{\circ} \mathrm{C}$ at $4^{\circ} \mathrm{C} / \mathrm{min}$. The sample injection volume was $1 \mu \mathrm{L}$ with a split ratio of $1: 20$. The carrier gas used was $\mathrm{N}_{2}(40 \mathrm{psi})$ at a flow rate of $45 \mathrm{~mL} / \mathrm{min}$, air and hydrogen flow rates were 30 $\mathrm{mL} / \mathrm{min}$ and $300 \mathrm{~mL} / \mathrm{min}$ respectively. Standard fatty acids, obtained from local vendor were injected to GC and identification of individual fatty acids was carried out by comparing the retention times of fatty acid samples with that of the reference. The percentage fatty acid compositions were obtained from their peak areas.

\subsection{Transesterification of the Mixed Oil Under Various Conditions}

Depending on the FFA contents of the feedstock, four major processes i.e., dilution, microemulsification, pyrolysis and transesterification may be used to produce biodiesel (Canakci, 2007). Transesterification is the most popular method to produce biodiesel using an alcohol in the presence or absence of a catalyst (Moser, 2009). In this study, a mixture of castor and microalgal oil (1:1 ratio) was added to a three necked round bottom flask preheated to a temperature of $60^{\circ} \mathrm{C}$ (Fig. 6). The reactor was submerged in a water bath placed on a plate with magnetic stirrer. The catalyst-alcohol solution was prepared freshly in order to maintain the catalytic activity and to prevent moisture absorbance. The catalyst-alcohol solution was added to the preheated reactor containing the oil mixture under constant mixing speed. The mixing speed was kept constant at $400 \mathrm{rpm}$ for all experimental runs. The experiments were carried out under varying conditions: reaction temperatures $\left(25^{\circ} \mathrm{C}\right.$ to $75^{\circ} \mathrm{C}$, catalyst concentrations ( $0.5 \%$ to $1.5 \% \mathrm{wt}$ ) and ethanol to oil molar ratios (3:1 to $12: 1)$ to find out the 
optimum conditions for the biodiesel production. At the end of each experimental condition samples were collected through the dilution of $0.10 \mathrm{~g}$ of the reaction products in $10 \mathrm{~mL}$ of tetrahydrofuran. Then, the samples were filtered and analyzed using high performance liquid chromatography (600 HPLC) to determine percentage yield of biodiesel.

Once the reaction was complete, excess ethanol was evaporated using a rotary-evaporator. Finally the fatty acid ethyl esters (biodiesel) and glycerol mixture was allowed to separate gravitationally in a separator funnel into two distinct layers. The two layers were finally separated by draining the glycerol layer from the bottom of the funnel. The biodiesel yield was measured using the following expression:

Biodiesel yield $(\%)=\frac{\text { Wt of Biodiesel obtained }}{\text { Wt of oil used }} \times 100$

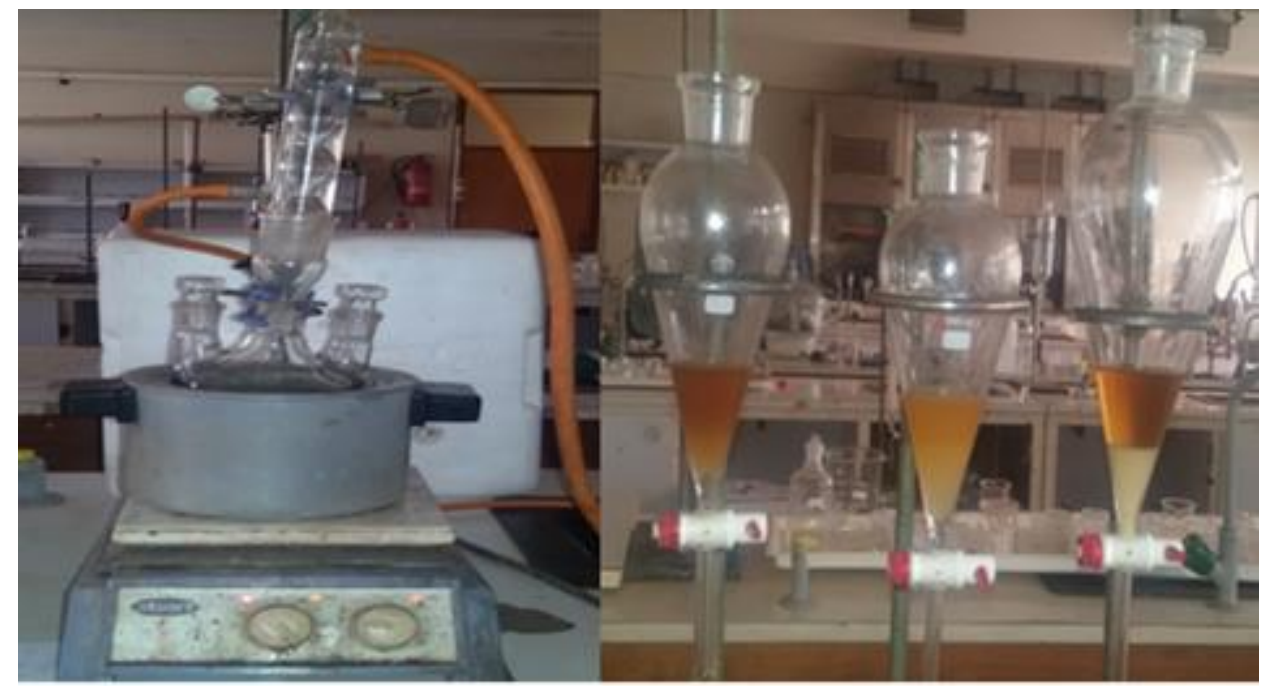

Fig. 6: Mixed oil tranisterification and separation of resulting biodiesel

\subsection{Purification of The Crude Biodiesel}

After separating from the glycerol layer, the crude biodiesel contains many impurities including soap, water, glycerides, excess catalyst and unreacted alcohol (Dennis Y.C. Leung et al., 2010). To comply with international quality standards (e.g., ASTM D751 and EN 14214), the crude biodiesel was purified to reduce the concentration of the impurities to acceptable levels (Tabatabaei et al., 2015). This is due to the fact that impurities are detrimental to the stability of biodiesel, storage tanks and combustion systems. In this study, the biodiesel was purified by washing with hot distilled water at $60^{\circ} \mathrm{C}$ (Fig. 5) until the washing water achieved a neutral $\mathrm{pH}$. Any remaining moisture was removed from the 
biodiesel by drying at $80^{\circ} \mathrm{C}$ under vacuum rotary evaporator and passing the ester layer over anhydrous sodium sulfate (Pradhan et al., 2012).

\subsection{Design of Experiment}

The conversion efficiency of feedstock depends on conditions of transesterification process. So the effects of those variables on yield of biodiesel were evaluated to determine optimum conditions (Banković-Ilić et al., 2012) In the classical experiments, optimization is usually carried out by varying one variable while keeping all others constant at a specific set of conditions. This optimization technique is not only time consuming and costly but also requires a large number of experiments to optimize variable conditions (Pradhan et al., 2012). The limitations of classical method of optimization can be overcome using design of experiment. Response Surface Methodology (RSM) is an effective statistical technique to design experiment to investigate the effects of individual factors and interactions between them on process optimization (Banković-Ilić et al., 2012).

Table 1: Actual and coded values of independent variables used in the CCD

\begin{tabular}{|l|c|c|c|c|c|c|c|}
\hline Factor & Symbol & Unit & \multicolumn{5}{|c|}{ Coded levels of independent factors } \\
\cline { 4 - 8 } & & & --1.68 & -1 & 0 & +1 & +1.68 \\
\cline { 4 - 8 } & & & \multicolumn{5}{|c|}{ Actual levels of independent factors } \\
\hline Catalyst concentration & $\mathrm{A}$ & $\%$ & 0.50 & 0.70 & 1 & 1.3 & 1.5 \\
\hline Alcohol to oil ratio & $\mathrm{B}$ & - & 3 & 5 & 7.5 & 10 & 12 \\
\hline Reaction temperature & $\mathrm{C}$ & ${ }^{\circ} \mathrm{C}$ & 25 & 35 & 50 & 65 & 75 \\
\hline
\end{tabular}

In this study, Central Composite Design (CCD) of RSM was used to evaluate the effects of individual process variables and interaction between them to determine optimum levels of transesterification process variables for mixed oil using alkaline catalyst. Experiments were conducted according to a $2^{\mathrm{n}}$ complete factorial for the three independent variables which gave a total of 17 experimental runs $\left(2^{n}+2 n+C P\right)$ where $n$ is the number of independent variables studied and CP is the number of central point. Each factor was varied over five levels. Eight factorial $\left(2^{n}\right)$ and six axial experimental runs $(2 n)$ were carried out with three extra replications at the center point to evaluate the pure error (Pradhan et al., 2012). The distance of the axial points from the center point was calculated using the expression $\pm \alpha=$ $\left(2^{\mathrm{n}}\right)^{1 / 4}$ where $\mathrm{n}$ is the number of independent variables and thus the value of $\alpha$ (alpha) was 
limited at level 1.68. Accordingly the lowest and highest levels assigned were -1.68 and +1.68 respectively. The axial points were located at $( \pm \alpha, 0,0),(0, \pm \alpha, 0)$ and $(0,0, \pm \alpha)$ for the three independent variables where $\alpha$ is the distance of the axial point from center point (Table 1). Transesterification of mixed oil was carried out at various catalytic concentrations $(0.50 \leq$ $\mathrm{A} \leq 1.5 \%)$, alcohol to oil molar ratios $(3: 1 \leq \mathrm{B} \leq 12: 1)$ and reaction temperatures $\left(25^{\circ} \mathrm{C} \leq \mathrm{C} \leq\right.$ $75^{\circ} \mathrm{C}$ ). The mixing speed and reaction time were set at optimum points for all experimental runs and ranges and levels of variables based on previous studies (Banković-Ilić et al., 2012; Pradhan et al., 2012). Levels of independent variables were selected based on the operating limit of transesterification process and literature data (Nivea et al., 2006; Pradhan et al., 2012). The highest reaction temperature level $\left(75^{\circ} \mathrm{C}\right)$ was chosen just below the boiling point of ethanol alcohol $\left(78^{\circ} \mathrm{C}\right)$ whereas the lowest reaction level chosen was room temperature $\left(25^{\circ} \mathrm{C}\right)$. The highest level $(1.5 \%)$ and lowest level $(0.50 \%)$ of catalyst concentrations were chosen based on literature data (Nakpong \& Wootthikanokkhan, 2010; Nivea et al., 2006; Pradhan et al., 2012). The lowest level of ethanol to oil molar ratio (3:1) was chosen based on the minimum stoichiometric amount of alcohol required for the transesterification reaction whereas the highest level (12:1) was chosen based on previous studies (Nakpong \& Wootthikanokkhan, 2010) The catalyst concentration of $1.0 \% \mathrm{w} / \mathrm{w}$, ethanol to oil molar ratio of 7.5:1 and reaction temperature of $50^{\circ} \mathrm{C}$ were selected as center points (zero levels) for the experimental design (Table 1).

\subsubsection{Statistical Analysis}

The experimental data were analyzed using the quadratic model to establish the relationship between percentage yield of biodiesel and independent variables. The complete model equation describes the contributions of the various variables on the yield of biodiesel (\%), determines the significance of the different levels of variables and optimum conditions at different levels (Pradhan et al., 2012). The relationship between variables at the center and interactions of the coded variables $X i$ on the percentage yield of biodiesel $(\mathrm{Z})$ is expressed by the following expression:

$Z=\beta_{0}+\sum_{i=1}^{n} \beta_{i} X_{i}+\sum_{i=1}^{n} \beta_{i i} x X_{i}^{2}+\sum_{i=1}^{n} \sum_{j<i}^{n} \beta_{i j} x X_{i j}$

Where $\mathrm{Z}$ is the percent of biodiesel yield; $\beta \mathrm{o}, \beta \mathrm{i}, \beta \mathrm{ii}, \beta \mathrm{ij}$ are respectively intercept, linear, quadratic and interaction constant coefficients; $n$ is the number of independent factors studied 
and optimized (three in this case) whereas $\mathrm{Xij}$ is the coded independent variable. Experiments were conducted to validate the model equation, using combinations of the independent variables at the optimum conditions. Regression and graphical analyses were carried out using Design Expert® Version 12 software. The quality of the model was evaluated using the coefficients of variation $\left(\mathrm{R}^{2}\right)$ and analysis of variance (ANOVA). Response surface plots were drawn by varying two of the independent variables while keeping the third variable constant.

\section{RESULTS AND DISCUSSION}

\subsection{Oil Extraction and Refining}

$25 \mathrm{~g}$ castor seeds dried in an oven at $105^{\circ} \mathrm{C}$ for 6 hours were used to determine the moisture content of castor seeds. The process was repeated three times and the average moisture content was determined using Eqn. 1. The average moisture content of castor seeds was found to be $14.43 \%$ wt. Similarly the moisture content of dried microalgal paste was found to be $10.5 \%$ wt. These results are beyond the allowable limit for effective transesterification using alkaline catalyst. Excess moisture content of the crude oil must be reduced to an acceptable level before the oil is converted to biodiesel as it reacts with catalyst to form soap during transesterification process as well as the produced soap also make the separation of biodiesel and glycerol difficult at the end of the reaction. The Saponification value $(\mathrm{mgKOH} / \mathrm{g})$ of mixed oil was found to be 180.90, a value within acceptable range. Higher saponification value decreases biodiesel yield by forming soap in presence of an alkaline catalyst. This is why a lower saponification value is preferred to obtain a higher biodiesel yield. The iodine number measures the double bonds present in oil which determines its degree of unsaturation. A higher iodine number may lead to deposit formation in engine injectors. The iodine value of the mixed oil was found to be $83.82\left(\mathrm{gI}_{2} / 100 \mathrm{~g}\right)$, a result within acceptable range. To determine the oil content of dried microalgae, $2.54 \mathrm{~kg}$ biomass was used to extract $800.40 \mathrm{~g}$ of oil using methanol as solvent. A $100 \mathrm{~g}$ of dried castor seed powder was used to extract $46.20 \mathrm{~g}$ of castor oil using methanol as solvent. The use of methanol to extract castor and microalgal oils is because both oils contain unsaturated fatty acids which are soluble in methanol (Haldar, 2018). The oil content of dried microalgal paste and powdered castor seeds was estimated using Eqn. 2 and found to be $31.51 \%$ and $46.21 \%$ respectively. These results are in a good agreement with the results reported in the literature 
for castor seeds (46 - 55\%) and microalgae (20 - 50\%) (Keneni \& Marchetti, 2017; Singh \& Singh, 2010).

\subsection{Physicochemical Properties of Mixed Oil and Biodiesel}

The various physicochemical properties of mixed oil (1:1 ratio) were evaluated using American Standard of Testing Materials (ASTM D751) and empirical formulas suggest by different authors. The physicochemical properties determined for mixed oil were specific gravity, density at $20^{\circ} \mathrm{C}$, kinematic viscosity @ $40{ }^{\circ} \mathrm{C}$, iodine value, flash point, Cetane number, caloric value, saponification value, acid value and free fatty acid value. Cetane number $(\mathrm{CN})$ and caloric value were estimated using empirical formula suggested by (Nascimento et al., 2013) (Eqn. 11) and (Demirbaş, 1998) (Eqn.12) respectively using titration results of iodine and saponification values. American Society for Testing and Materials (ASTM) standards and European Union Biodiesel (EN14214) specifications were used to investigate fuel properties of biodiesel produced from mixed oil under the optimal conditions to confirm the suitability of the biodiesel in the existing diesel engine. Table 2 shows the physicochemical properties of mixed oil and fuel properties of biodiesel produced from it as compared to ASTM standards and EN 14214 specifications. The iodine value of mixed oil was found to be $82.22 \mathrm{gI}_{2} / 100 \mathrm{~g}$ which is within acceptable range of ASMT standards. The acid and free fatty acid values of the mixed oil $(0.21 \mathrm{mgKOH} / \mathrm{g}$ and 0.10 $\mathrm{mgKOH} / \mathrm{g}$ respectively) signify that the oil must be neutralized before converted to biodiesel via transesterification if alkaline catalyst must be used. Accordingly the acid value of mixed oil was neutralized with $0.50 \mathrm{~N} \mathrm{NaOH}$ to reduce the acid value to less than $0.050 \%$. The density of mixed oil at $20{ }^{\circ} \mathrm{C}$ was found $890 \mathrm{~kg} / \mathrm{m}^{3}$ while it was $920 \mathrm{~kg} / \mathrm{m}^{3}$ for the biodiesel produced from it. To obtain the density of mixed oil specific gravity was multiplied by density of water $\left(1000 \mathrm{~kg} / \mathrm{m}^{3}\right)$ and found to be $920 \mathrm{~kg} / \mathrm{m}^{3}$.

Viscosity of biodiesel is closely related to the length of fatty acid chain. It increases with increase in the chain of fatty acid. Reducing viscosity is the main objective for the transesterification of oils. This is due to the fact that, viscosity affects the formation of engine deposits and atomization during fuel injection into combustion chamber (Bouaziz et al., 2017). The viscosity of biodiesel produced from the mixed oil is found within acceptable range of ASTM D6751 standards. Flash point (FP) is the minimum temperature at which the vapour above a fuel becomes flammable. It is an important parameter to assess fire risk 
during transportation, storage and use of biodiesel. Petro-diesels have flashpoints from $50^{\circ} \mathrm{C}$ $80^{\circ} \mathrm{C}$ while biodiesel has a flashpoint of over $160^{\circ} \mathrm{C}$ (Abdulkadir, 2015). The flash pint of the biodiesel from mixed falls within both EN 14214 and ASTM D6751 standards. Cetane number $(\mathrm{CN})$ is a measure of ignition quality of a fuel (biodiesel). The higher the $\mathrm{CN}$ value, the easier the biodiesel ignites when injected into an engine. Diesel fuels are required to have $\mathrm{CN}$ value of 40 to 45 . Biodiesel has a higher $\mathrm{CN}$ value $(46-60)$ because of its higher oxygen content (Meher et al., 2006). Cetane number in mixed oil was found to be 57.44 while it was 58.12 for the biodiesel produced from it. The results revealed that there is a significant improvement in the physicochemical properties of the biodiesel derived from mixed. Accordingly the kinematic viscosity at $40^{\circ} \mathrm{C}$, density at $20^{\circ} \mathrm{C}$, calorific value, acid value, iodine value and flash point are respectively $5.8 \mathrm{~mm}^{2} / \mathrm{s}, 920 \mathrm{~kg} / \mathrm{m}^{3}, 48.0 \mathrm{MJ} / \mathrm{kg}, 0.01 \mathrm{mg}$ $\mathrm{KOH} / \mathrm{g}, 82.22\left(\mathrm{~g} \mathrm{I}_{2} / 100 \mathrm{~g}\right)$ and $133.33\left({ }^{\circ} \mathrm{C}\right)$.

Table 2: Physicochemical properties of mixed oil and biodiesel derived from it

\begin{tabular}{|l|c|c|c|c|c|}
\hline Physicochemical property & \multirow{2}{*}{ Unit } & \multicolumn{2}{|c|}{ Values } & \multicolumn{2}{c|}{ Biodiesel standards } \\
\cline { 2 - 5 } & & Mixed oil & Biodiesel & ASTM D751 & EN 14214 \\
\hline Specific gravity & - & 0.89 & 0.920 & $0.86-0.90$ & $0.86-0.90$ \\
\hline Density at $20{ }^{\circ} \mathrm{C}$ & $\mathrm{Kg} / \mathrm{m}^{3}$ & 890 & 920 & $860-900$ & $860-900$ \\
\hline Kinematic viscosity @ 40 ${ }^{0} \mathrm{C}$ & $\mathrm{mm}^{2} / \mathrm{s}$ & 44.60 & 5.80 & $1.9-6.0$ & $3.5-5.0$ \\
\hline Flash point & ${ }^{0} \mathrm{C}$ & 160 & 133.33 & $\geq 120$ & $\geq 130$ \\
\hline Cetane number & - & 57.44 & 58.12 & $\geq 47$ & $\geq 51$ \\
\hline Acid value & $\mathrm{mg} \mathrm{KOH} / \mathrm{g}$ & 0.21 & 0.10 & $\leq 0.05$ & $\leq 0.05$ \\
\hline Free fatty acid value & $\%$ & 0.11 & 0.05 & - & - \\
\hline Saponification value & $\mathrm{mg} \mathrm{KOH} / \mathrm{g}$ & 180.9 & 1.80 & - & - \\
\hline Iodine Value & $\mathrm{g} \mathrm{I} / 100 \mathrm{~g}$ & 83.82 & 82.22 & $\leq 120$ & $\leq 140$ \\
\hline Moisture content & $\%$ & 0.06 & 0.027 & $\leq 0.03$ & Max 0.05 \\
\hline Ash content & $\%$ & 0.045 & 0.028 & $\leq 0.03$ & $\leq 0.02$ \\
\hline Caloric value & $\mathrm{MJ} / \mathrm{Kg}$ & 43.27 & 48.0 & $\geq 42$ & $\geq 35$ \\
\hline
\end{tabular}

The FFA composition of mixed oil and biodiesel produced from it was analyzed using Gas Chromatography. GC analysis of microalgal oil indicates that it is composed of unsaturated fatty acids such as palmitolleic (16:1), oleic (18:1), linoleic (18:2), linolenic acid (18:3) and a small amount of saturated fatty acids such as palmitic (16:0) and stearic (18:0). On the other 
hand the castor oil is composed of ricinoleic acid $(\mathrm{C} 18: 1 \mathrm{OH})$, linoleic acid (C18:2), oleic acid (C18:1), palmitic acid (C16:0), stearic acid (C18:0) and linolenic acid (C18:3).

\subsection{Optimization of Transesterification Conditions by Response Surface Methodology}

\subsubsection{Model Fitting and Analysis of variance (ANOVA)}

Response Surface Methodology (RSM) comprising of Central Composite Design (CCD) with five level-three factor design was used to optimize conditions for transesterification of mixed oil. Experimental parameters, ranges and levels of independent variables investigated and results of the CCD design are shown in Table 4. The results of seventeen experiments designed by CCD were analyzed using Design-Expert® Version 12 software. A quadratic polynomial equation consisting of a center point, three linear coefficients $(A, B, C)$, three quadratic coefficients $\left(\mathrm{A}^{2}, \mathrm{~B}^{2}, \mathrm{C}^{2}\right)$ and three interaction coefficients $(\mathrm{AB}, \mathrm{AC}, \mathrm{BC})$ was obtained from the design experiment for predicting the yield of biodiesel in terms of code factors according to the following expression:

Biodiesel yield $=91.28+11.69 \mathrm{~A}+4.76 \mathrm{~B}-0.83 \mathrm{C}-5.15 \mathrm{AB}+1.84 \mathrm{AC}-1.63 \mathrm{BC}-8.20 \mathrm{~A}^{2}-$ $3.54 \mathrm{~B}^{2}-0.069 \mathrm{C}^{2}$

However, only terms with $\mathrm{P}$-value $<0.05$ were included in the final model equation for characterizing the response. The model was analyzed statistically to evaluate the analysis of variance (ANOVA) and if adequate to fit.

The P-value of the model is less than 0.0001 indicating high significance in predicting the response and suitability of the model. The $\mathrm{F}$ value of model $(\mathrm{F}=54.96)$ with very low $\mathrm{P}$ value $(<0.0001)$ indicates the high significance of the fitted model. A small coefficient of variation $(\mathrm{CV}=5.39 \%)$ indicates the reliability of fitted model. The quality of the model fit was evaluated by the coefficient of variation $\left(\mathrm{R}^{2}=0.9860\right.$ which implies $98.6 \%$ of the experimental data are compatibility with the data predicted by the model).

The significance of each coefficient of response surface model was evaluated using P-values. Accordingly only A (catalyst concentration linear term, $\mathrm{P}<0.0001$ ), B (molar ratio of ethanol to oil linear term, $\mathrm{P}=0.0003$ ), $\mathrm{A}^{2}$ (catalyst concentration quadratic term, $\mathrm{P}<0.0001$ ), $\mathrm{B}^{2}$ (ethanol to oil molar ratio quadratic term, $\mathrm{P}=0.0028$ ) and $\mathrm{AB}$ (interaction between catalyst concentration and ethanol to oil molar ratio, $\mathrm{P}=0.0011$ ) coefficients were significant. All coefficients containing temperature terms (linear, interactions, quadratic) were not significant (Table 5). 
The adjusted coefficient of variation ( $\mathrm{R}^{2}$ adjusted) was used to rewrite model equation using all the significant terms. A very high value of the adjusted coefficient of variation $\left(\mathrm{R}^{2}\right.$ adjusted $=0.968$ ) indicates the model is very significant. A reasonable precision of the fitted model was deduced from a high value of predicted coefficient of variation $\left(\mathrm{R}^{2}\right.$ predicted $=$ 0.9214). A reasonably high value of coefficient of variation $\left(\mathrm{R}^{2}=0.9860\right)$ indicates that the model is in agreement with the observed values over the selected range of operating parameters (Fig. 7).

Table 4: Experimental design using CCD and results of mixed oil transesterification

\begin{tabular}{|c|c|c|c|c|c|c|c|c|c|c|}
\hline \multirow{3}{*}{$\begin{array}{l}\text { Design } \\
\text { by } \\
\text { CCD }\end{array}$} & \multirow[t]{3}{*}{ Run } & \multicolumn{3}{|c|}{ Actual levels of factors } & \multirow{2}{*}{\multicolumn{3}{|c|}{ Coded level of factors }} & \multicolumn{2}{|c|}{ Biodiesel yield (\%) } & \multirow{3}{*}{ 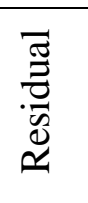 } \\
\hline & & \multirow{2}{*}{$\begin{array}{c}\text { Catalyst } \\
\text { conc. } \\
(\%)\end{array}$} & \multirow{2}{*}{$\begin{array}{l}\text { Molar } \\
\text { ratio }\end{array}$} & \multirow{2}{*}{$\begin{array}{l}\text { Reaction } \\
\text { temperature } \\
\left({ }^{\circ} \mathrm{C}\right)\end{array}$} & & & & & & \\
\hline & & & & & A & $\mathrm{B}$ & $\mathrm{C}$ & Actual & Predicted & \\
\hline \multirow{8}{*}{ 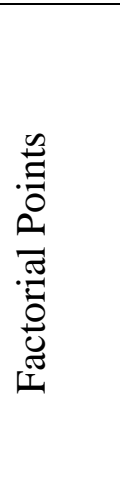 } & 1 & 1.3 & 10 & 35 & 1 & 1 & -1 & 90.87 & 91.67 & -0.80 \\
\hline & 2 & 0.7 & 10 & 35 & -1 & 1 & -1 & 82.22 & 81.50 & 0.72 \\
\hline & 3 & 1.3 & 5 & 65 & 1 & -1 & 1 & 91.94 & 94.53 & -2.59 \\
\hline & 4 & 1.3 & 10 & 65 & 1 & 1 & 1 & 89.44 & 90.66 & -1.22 \\
\hline & 5 & 0.7 & 5 & 35 & -1 & -1 & -1 & 59.19 & 59.83 & -0.64 \\
\hline & 6 & 1.3 & 5 & 35 & 1 & -1 & -1 & 88.49 & 89.43 & -0.94 \\
\hline & 7 & 0.7 & 10 & 65 & -1 & 1 & 1 & 72.13 & 73.06 & -0.93 \\
\hline & 8 & 0.7 & 5 & 65 & -1 & -1 & 1 & 56.44 & 57.51 & -1.07 \\
\hline \multirow{6}{*}{ 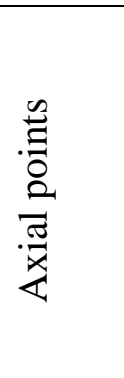 } & 9 & 1.5 & 7.5 & 50 & 2 & 0 & 0 & 90.19 & 87.76 & 2.43 \\
\hline & 10 & 1 & 12 & 50 & 0 & 2 & 0 & 89.59 & 89.28 & 0.31 \\
\hline & 11 & 0.5 & 7.5 & 50 & -2 & 0 & 0 & 48.68 & 48.43 & 0.25 \\
\hline & 12 & 1 & 3 & 50 & 0 & -2 & 0 & 75.25 & 73.26 & 1.99 \\
\hline & 13 & 1 & 1.5 & 75 & 0 & 0 & 2 & 92.23 & 89.68 & 2.55 \\
\hline & 14 & 1 & 7.5 & 25 & 0 & 0 & -2 & 92.57 & 92.48 & 0.09 \\
\hline \multirow{3}{*}{$\stackrel{\stackrel{\oplus}{0}}{\stackrel{\mathscr{D}}{\Xi}}$} & 15 & 1 & 7.5 & 50 & 0 & 0 & 0 & 93.34 & 91.28 & 2.06 \\
\hline & 16 & 1 & 7.5 & 50 & 0 & 0 & 0 & 92.43 & 91.28 & 1.15 \\
\hline & 17 & 1 & 7.5 & 50 & 0 & 0 & 0 & 87.89 & 91.28 & -3.39 \\
\hline
\end{tabular}

\subsubsection{Effects of the Process Variables on the Yield of Biodiesel}

Design Expert ${ }^{\circledR} 12$ software was used to draw response surface plots using regression model equation. Since individual plot does not show the significant interaction between parameters involved, 3D surface and Contour plots were drawn to show the interaction effect of process 
variables on percentage yield of biodiesel. Each contour plot represents effect of two independent variables on the biodiesel yield, keeping the third variable at a fixed level (zero level). Based on 95\% confidence limit, only those terms with P-value $<0.05$ were considered in the final quadratic model equation to investigate the effect of independent variables on the yield of biodiesel. The reduced significant model equation is:

$Z=91.28+11.69 \mathrm{~A}+4.76 \mathrm{~B}-5.15 \mathrm{AB}-8.20 \mathrm{~A}^{2}-3.54 \mathrm{~B}^{2}$

Accordingly, the linear and quadratic terms of ethanol to oil molar ratio and catalyst concentration $\left(\mathrm{A}, \mathrm{A}^{2}\right.$ and $\mathrm{B}, \mathrm{B}^{2}$ ) were statistically significant. On the other hand, all the interaction terms were not statistically significant except between ethanol to mixed oil molar ratio and catalyst concentration $(\mathrm{AB})$.

Table 5: Analysis of variance (ANOVA) for fitting the response surface quadratic model

\begin{tabular}{|c|c|c|c|c|c|c|}
\hline $\begin{array}{l}\text { Variation } \\
\text { source }\end{array}$ & Sum of Squares & DF & Mean Square & F-value & P-value & \\
\hline Model & 3268.62 & 9 & 363.18 & 54.96 & $<0.0001$ & Significant \\
\hline A-Catalyst & 1887.19 & 1 & 1887.19 & 285.61 & $<0.0001$ & \\
\hline B-Molar ratio & 286.53 & 1 & 286.53 & 43.36 & 0.0003 & \\
\hline C-Temperature & 9.50 & 1 & 9.50 & 1.44 & 0.2695 & \\
\hline $\mathrm{AB}$ & 188.57 & 1 & 188.57 & 28.54 & 0.0011 & \\
\hline $\mathrm{AC}$ & 27.60 & 1 & 27.60 & 4.18 & 0.0803 & \\
\hline $\mathrm{BC}$ & 18.67 & 1 & 18.67 & 2.82 & 0.1367 & \\
\hline $\mathrm{A}^{2}$ & 750.30 & 1 & 750.30 & 113.55 & $<0.0001$ & \\
\hline $\mathrm{B}^{2}$ & 134.19 & 1 & 134.19 & 20.31 & 0.0028 & \\
\hline $\mathrm{C}^{2}$ & 0.0522 & 1 & 0.0522 & 0.0079 & 0.9317 & \\
\hline Residual & 46.25 & 7 & 6.61 & - & - & \\
\hline Lack of fit & 29.21 & 5 & 5.84 & 0.6853 & 0.6832 & Not significant \\
\hline Pure error & 17.05 & 2 & 8.52 & - & - & \\
\hline Total & 3314.88 & 16 & - & - & - & \\
\hline
\end{tabular}




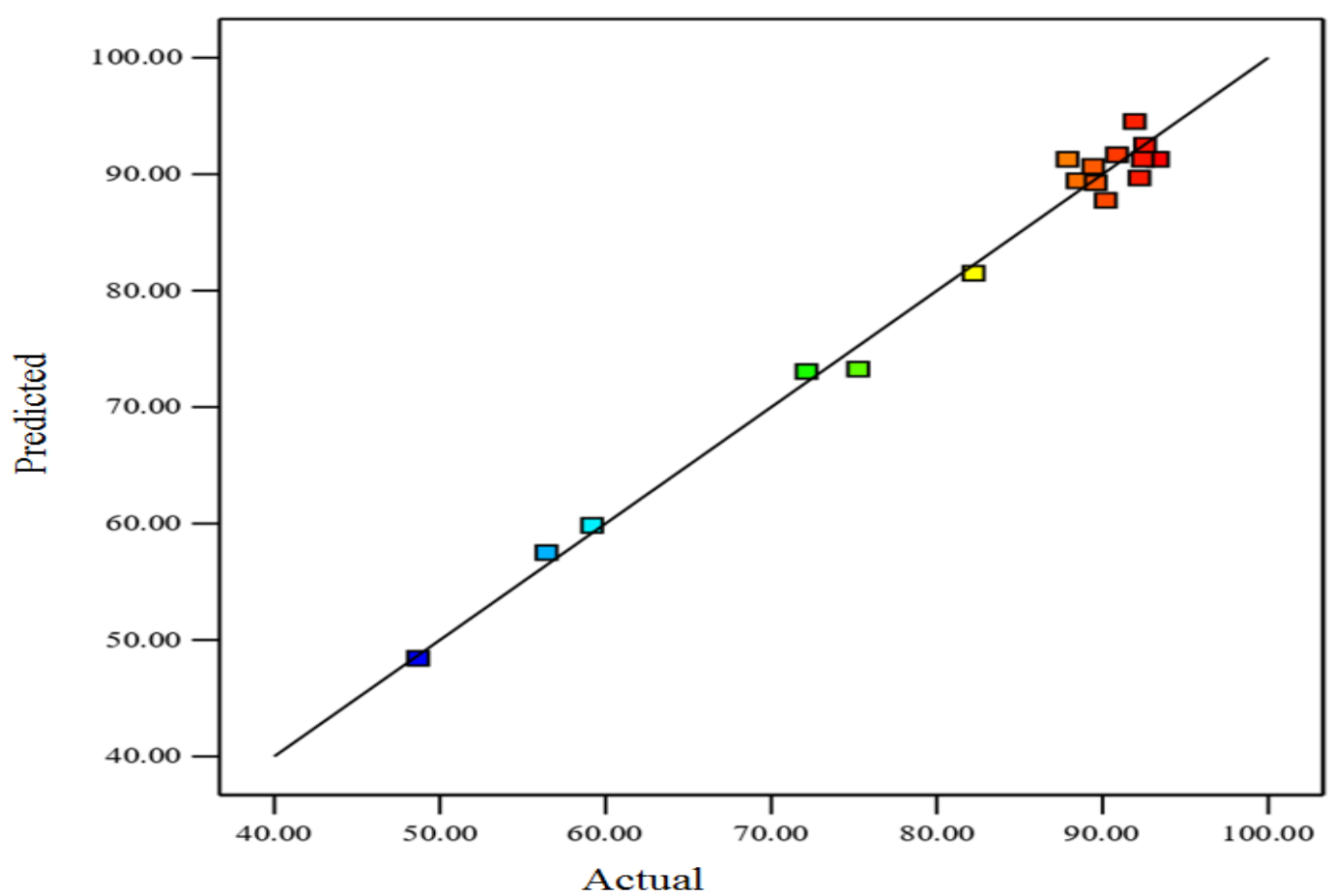

Fig. 7: Comparison between actual and predicted value of biodiesel yield

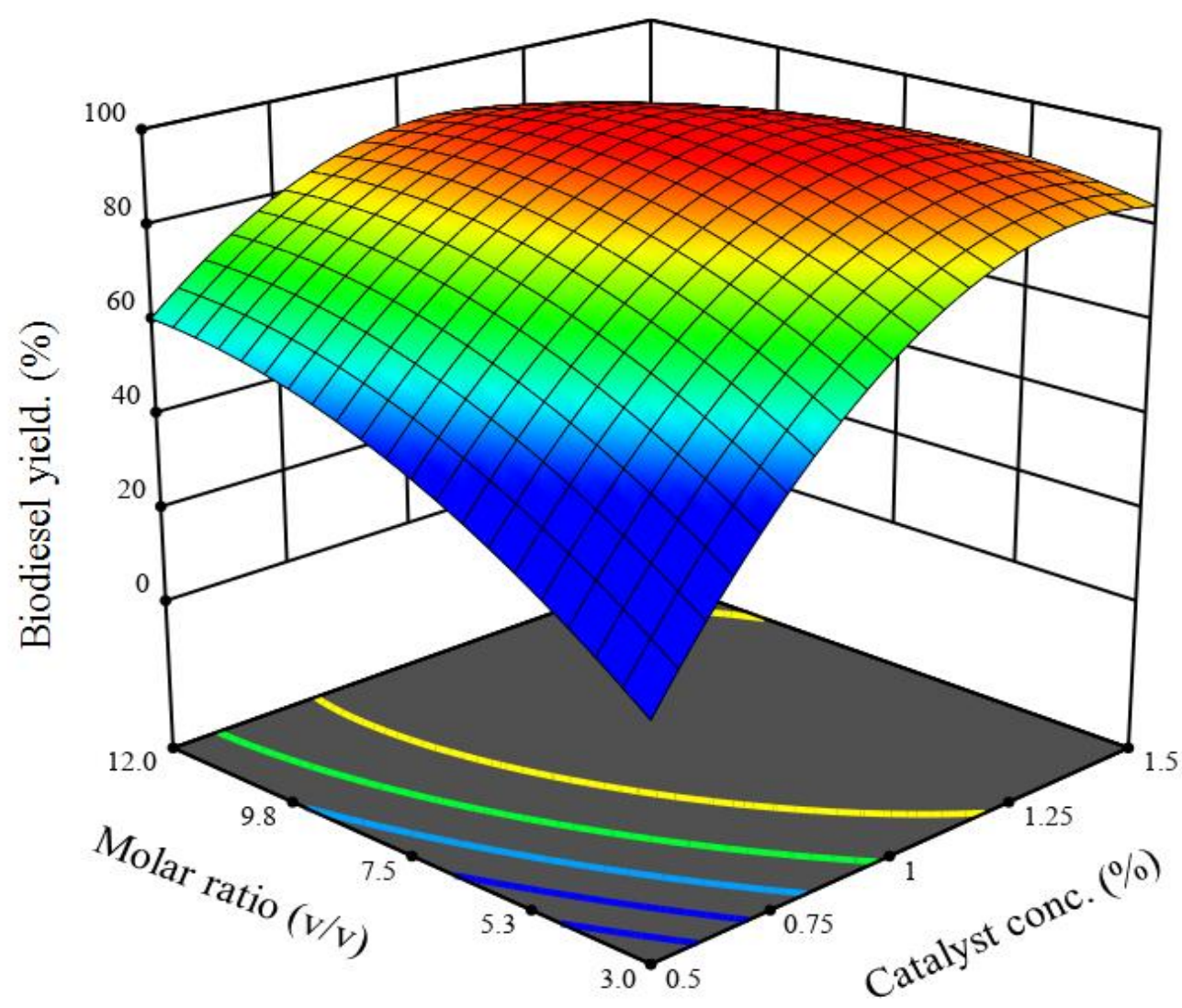

Fig. 8: Effect of ethanol to oil molar ratio and catalyst concentration on yield of biodiesel at constant reaction temperature of $50^{\circ} \mathrm{C}$ 
The effect ethanol to mixed oil molar ratio and catalyst concentration on yield of biodiesel at a constant reaction temperature of $50^{\circ} \mathrm{C}$ is shown in Fig. 8. The relationship between percentage yield of biodiesel and catalyst concentration is curvilinear with a positive linear coefficient and a negative quadratic coefficient indicating that yield of biodiesel is inhibited beyond the optimum catalyst concentration might be because revers reaction is favored at higher catalyst concentration. At low ethanol to oil molar ratio, the yield of biodiesel was improved with increase in catalyst concentration. However, the rate of transesterification decreases beyond optimum catalyst concentration might be because revers reaction is favored at higher catalyst concentration. Increasing both molar ratio and catalyst concentration at the same time also improved the yield of biodiesel, indicating that there is significant interaction between oil molar ratio and catalyst concentration.

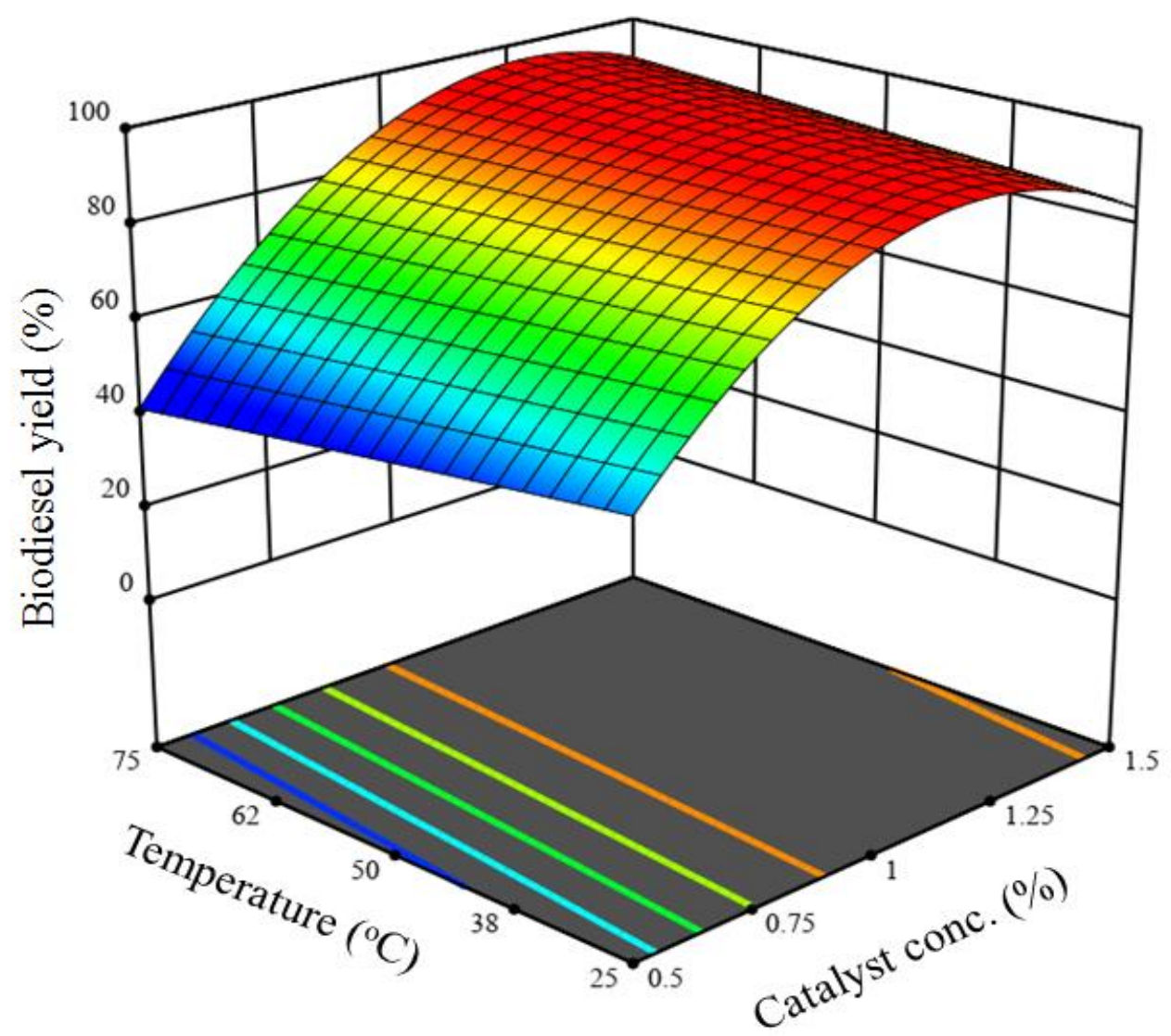

Fig. 9: Effect of reaction temperature and catalyst concentration on yield of biodiesel at constant ethanol to oil molar ratio of 7.5:1

The effect of reaction temperature and catalyst concentration on the yield of biodiesel at a constant ethanol to oil molar ratio of 7.5:1 is shown in Fig. 9. The effect of reaction 
temperature (C) and its interactions with catalyst concentration (AC) was not significant at Pvalue $=0.05$, indicating that temperature does not significantly affect the yield of biodiesel. The yield of biodiesel was improved with increases in catalyst concentration towards $1.23 \%$ at room temperature and after that there was substantial decrease in yield of biodiesel with further increase in catalyst concentration. This might be due to the fact that excess amount of catalyst concentration decreases the yield of biodiesel due to soap formation. The formation of soap occurs due to saponification reaction at higher catalytic concentration beyond $1.25 \%$.

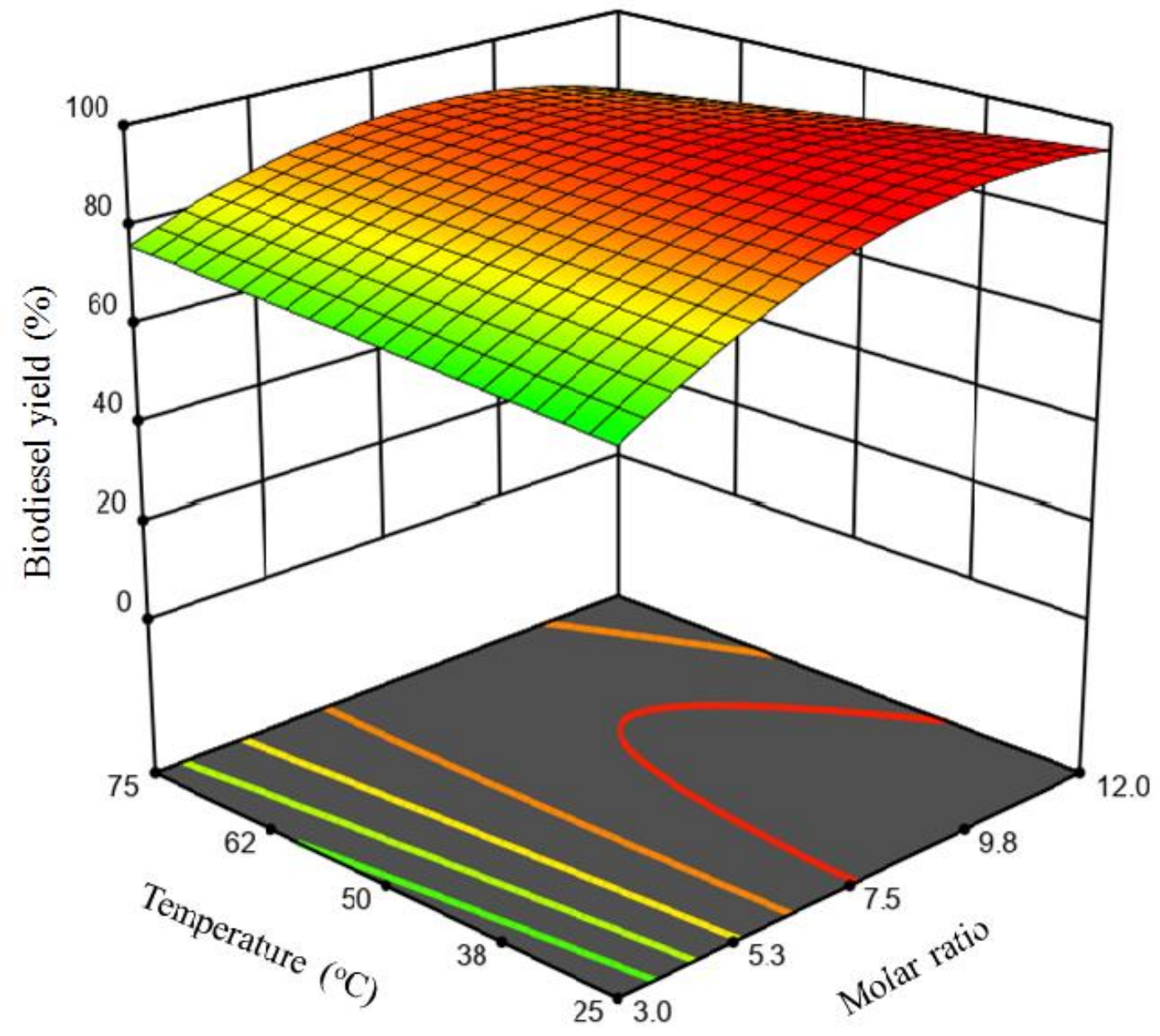

Fig. 10: Effect of reaction temperature, ethanol to mixed oil molar ratio and their combined interaction on the yield of biodiesel at constant catalyst concentration of $1 \% \mathrm{wt}$.

The effect of molar ratio, reaction temperature and their combined interaction at constant catalyst concentration of $1 \%$ wt. is shown in Fig. 10. The effect of reaction temperature and its interactions with molar ratio $(\mathrm{BC})$ was not significant at $\mathrm{P}$-value $=0.05$, indicating that temperature does not significantly affect the yield of biodiesel might be due to the fact that the mixed oil is soluble in ethanol at room temperature. At low catalyst concentration 
increasing temperature had very little effect on the yield of biodiesel. Increasing molar ratio beyond the optimal will increase cost for alcohol recovery rather than increasing yield of biodiesel (Leung et al., 2010).

\subsubsection{Optimization of Process Variables}

The Design-Expert ${ }^{\circledR}$ Software was used to solve the regression equation to obtain optimal values for the three independent variables. The software tries to find the value of the process variables that gives maximum biodiesel yield. To solve the regression equation the goal of the three independent variables was set to "in range" while the goal of the response (percent of biodiesel yield) was set to "maximize". Both the lower and upper weights were set to one while importance was set at 3 (Table 6). The predicted optimal values obtained from the model were catalyst concentration of 1.23 w.t.\% of oil, ethanol to oil molar ratio of 5.94:1 and reaction temperature of $51.31{ }^{\circ} \mathrm{C}$. The model predicts that the maximum biodiesel yield under these optimum conditions is $93.88 \%$.

Table 6: Optimization of Transesterification Process Variables under Optimum Conditions

\begin{tabular}{|l|l|c|c|c|c|c|}
\hline Constraint Name & \multicolumn{1}{|c|}{ Goal } & $\begin{array}{c}\text { Lower } \\
\text { limit }\end{array}$ & Upper limit & $\begin{array}{c}\text { Lower } \\
\text { weight }\end{array}$ & $\begin{array}{c}\text { Upper } \\
\text { weight }\end{array}$ & Importance \\
\hline Catalyst & In range & 0.70 & 1.30 & 1 & 1 & 3 \\
\hline Molar ratio & In range & 4.8 & 10.20 & 1 & 1 & 3 \\
\hline Temperature & In range & 35 & 65 & 1 & 1 & 3 \\
\hline Biodiesel yield & Maximum & 48.68 & 93.34 & 1 & 1 & 3 \\
\hline \multicolumn{7}{|c|}{ Solution } \\
\hline Solution number & Catalyst & Molar & Reaction & Biodiesel \\
Conc. & ratio & temperature & yesirability & & Status \\
\hline 1 & 1.23 & 5.94 & 51.31 & 93.88 & 1.00 & Selected \\
\hline
\end{tabular}

Table 7: Model validation by experimental results under optimum conditions

\begin{tabular}{|c|c|c|c|c|}
\hline \multicolumn{3}{|c|}{ Optimum condition } & \multicolumn{2}{c|}{ Biodiesel yield (\%) } \\
\hline $\begin{array}{c}\text { Catalyst } \\
\text { Conc. }(\% \text { wt. })\end{array}$ & $\begin{array}{c}\text { Molar ratio } \\
(\mathrm{v} / \mathrm{v})\end{array}$ & Temperature $\left({ }^{\circ} \mathrm{C}\right)$ & $\begin{array}{c}\text { Experimental } \\
\text { result }\end{array}$ & Model predicted \\
\hline 1.23 & 5.94 & 51.31 & 93.36 & 93.88 \\
\hline
\end{tabular}


To validate result predicted by model, experiment was conducted under the specified optimum conditions. The yield of biodiesel from the experiment is $93.36 \%$ which is very close to the value predicted by the model (Table 7).

\section{Conclusions}

This study was conducted to optimize biodiesel production process parameters of a biodiesel derived from mixture of castor and microalgae oils using Response Surface Methodology. A 1:1 ratio of oil mixture was converted to biodiesel using alkali-catalysed transesterification process. Response surface methodology based on Central composite Design (CCD) experiment was used to maximize biodiesel yield from mixed oil. The optimum operating parameters for transesterification of mixed oil at $500 \mathrm{rpm}$ and reaction time of one hour were ethanol-to-oil molar ratio of 5.94:1, catalyst concentration of $1.23 \%$ and reaction temperature of $51.31^{\circ} \mathrm{C}$. Under these operating parameters the highest yield of biodiesel obtained was 93.36\%. American Society for Testing and Materials (ASTM) and European Union Biodiesel (EN14214) specifications standards were used to investigate fuel properties

of biodiesel produced from mixed oil under the optimal conditions to confirm the suitability of the biodiesel to the existing diesel engine. Study of physicochemical properties of the biodiesel produced from mixed oil reveals that the properties are within ASTM D6751 and EN14214 standards. Optimization of process parameters for biodiesel derived from mixed feedstocks is very important to improve the fuel properties of biodiesel. Therefore, it can be concluded that the optimized biodiesel from mixed oil is a potential substitute of diesel fuel but engine performance and exhaust emissions should be studied.

\section{DECLARATIONS}

\subsection{Declaration of Availability of data and Materials}

The datasets generated and/or analysed during the current study are available in the manuscript itself. However, if any further datasets are required they are available from the corresponding author upon reasonable request from the publisher.

\subsection{Declaration of Competing Interests}

The authors would like to declare that there are no potential conflicts of interest with respect to the research, authorship and/or publication of this article. 


\subsection{Declaration of Funding}

The authors would like to declare that no funding has been received to conduct this study.

\subsection{Declaration of Authors' Contributions}

The authors would like to declare that all authors contributed equally and all authors read and approved the final manuscript.

\subsection{Acknowledgements}

The authors would like to acknowledge Jimma University, Jimma Institute of Technology for providing financial support and analytical instruments to conduct this study.

\section{REFERENCES}

Abdulkadir, I. (2015). OPtimization Of Biodiesel Production from yellow Oleander and Castor Oils and studies Of their full Properties. 66, 37-39.

Abidin, S. Z. (2012). Production of Biodiesel from Used Cooking Oil (UCO) using Ion Exchange Resins as Catalysts. 244.

Asmare, M., \& Gabbiye, N. (2014). Synthesis and Characterization of Biodiesel from Castor Bean as Alternative Fuel for Diesel Engine. American Journal of Energy Engineering, 2(1), 1. https://doi.org/10.11648/j.ajee.20140201.11

Atabani, A. E., Silitonga, A. S., Badruddin, I. A., Mahlia, T. M. I., Masjuki, H. H., \& Mekhilef, S. (2012). A comprehensive review on biodiesel as an alternative energy resource and its characteristics. Renewable and Sustainable Energy Reviews, 16(4), 2070-2093. https://doi.org/10.1016/j.rser.2012.01.003

Avhad, M. R., \& Marchetti, J. M. (2015). A review on recent advancement in catalytic materials for biodiesel production. Renewable and Sustainable Energy Reviews, 50, 696-718. https://doi.org/10.1016/j.rser.2015.05.038

Babajide, O. O., Petrik, L., Supervisors, C.-, \& Ameer, F. (2011). Keywords Optimisation of Biodiesel Production via Different. November.

Banković-Ilić, I. B., Stamenković, O. S., \& Veljković, V. B. (2012). Biodiesel production from non-edible plant oils. Renewable and Sustainable Energy Reviews, 16(6), 36213647. https://doi.org/10.1016/j.rser.2012.03.002

Bhuiya, M. M. K., Rasul, M. G., Khan, M. M. K., Ashwath, N., Azad, A. K., \& Hazrat, M. A. (2016). Prospects of 2nd generation biodiesel as a sustainable fuel - Part 2: Properties, performance and emission characteristics. Renewable and Sustainable 
Energy Reviews, 55, 1129-1146. https://doi.org/10.1016/j.rser.2015.09.086

Bouaziz, M., Mahafoudhi, M., Jebeur, H., \& Neji, S. B. (2017). Biodiesel Production from Raw Tunisian Castor Oil and Its Application as Alternative Fuel. Archives of Petroleum \& Environmental Biotechnology, 2(3). https://doi.org/10.29011/2574-7614.100118

Canakci, M. (2007). The potential of restaurant waste lipids as biodiesel feedstocks. Bioresource Technology, 98(1), 183-190. https://doi.org/10.1016/j.biortech.2005.11.022

Chisti, Y. (2007). Biodiesel from microalgae. Biotechnology Advances, 25(3), 294-306. https://doi.org/10.1016/j.biotechadv.2007.02.001

De Lima Da Silva, N., Batistella, Ć. B., Filho, R. M., \& Maciel, M. R. W. (2009). Biodiesel production from castor oil: Optimization of alkaline ethanolysis. Energy and Fuels, 23(11), 5636-5642. https://doi.org/10.1021/ef900403j

Demirbas, A. (2005). Biodiesel production from vegetable oils via catalytic and non-catalytic supercritical methanol transesterification methods. Progress in Energy and Combustion Science, 31(5-6), 466-487. https://doi.org/10.1016/j.pecs.2005.09.001

Demirbaş, A. (1998). Fuel properties and calculation of higher heating values of vegetable oils. Fuel, 77(9-10), 1117-1120. https://doi.org/10.1016/S0016-2361(97)00289-5

Demirbas, A., Ak, N., Aslan, A., \& Sen, N. (2018). Calculation of higher heating values of hydrocarbon compounds and fatty acids. Petroleum Science and Technology, 36(11), 712-717. https://doi.org/10.1080/10916466.2018.1443126

Deng, X., Li, Y., \& Fei, X. (2009). Microalgae: A promising feedstock for biodiesel. African Journal of Microbiology Research, 3(13), 1008-1014.

Dharma, S., Masjuki, H. H., Ong, H. C., Sebayang, A. H., Silitonga, A. S., Kusumo, F., \& Mahlia, T. M. I. (2016). Optimization of biodiesel production process for mixed Jatropha curcas-Ceiba pentandra biodiesel using response surface methodology. Energy Conversion and Management, 115, 178-190. https://doi.org/10.1016/j.enconman.2016.02.034

Eevera, T., Rajendran, K., \& Saradha, S. (2009). Biodiesel production process optimization and characterization to assess the suitability of the product for varied environmental conditions. Renewable Energy, 34(3), 762-765. https://doi.org/10.1016/j.renene.2008.04.006

Fajardo, C. A. G., León, I. D. O., \& Vargas., F. E. S. (2010). Evaluating the effect of 
temperature on biodiesel production from castor oil. Ingenieria e Investigacion, 30(2), $52-61$.

Freedman B, Pyde, E. ., \& MOUNTs, T. . (1984). Cs 1 (Vol. 61, Issue 10). https://doi.org/10.1145/3017680.3017802

Haldar, C. (2018). Microalgae as a Potential Source of Biofuels and its Current Advances. Examines in Marine Biology \& Oceanography, 2(1), 168-172. https://doi.org/10.31031/eimbo.2018.02.000529

Hanna, M., \& Fangrui, M. (1999). Biodiesel production: a review 1. Bioresource Technology, 70, 1-15.

Hassani, M., Najafpour, G. D., \& Mohammadi, M. (2016). Transesterification of waste cooking oil to biodiesel using $\gamma$-alumina coated on zeolite pellets. Journal of Materials and Environmental Science, 7(4), 1193-1203.

Hurtado, B., Posadillo, A., Luna, D., Bautista, F. M., Hidalgo, J. M., Luna, C., Calero, J., Romero, A. A., \& Estevez, R. (2019). Synthesis, performance and emission quality assessment of ecodiesel from castor oil in diesel/biofuel/alcohol triple blends in a diesel engine. Catalysts, 9(1). https://doi.org/10.3390/catal9010040

Indhumathi, P., Syed Shabudeen, P. S., \& Shoba, U. S. (2014). A method for production and characterization of biodiesel from green micro algae. International Journal of BioScience and Bio-Technology, 6(5), 111-122. https://doi.org/10.14257/ijbsbt.2014.6.5.11

Jena, P. C., Raheman, H., Prasanna Kumar, G. V., \& Machavaram, R. (2010). Biodiesel production from mixture of mahua and simarouba oils with high free fatty acids. Biomass and Bioenergy, 34(8), 1108-1116. https://doi.org/10.1016/j.biombioe.2010.02.019

Johnson, W. Z. and M. B. (2009). Microalgae as a Feedstock for Biofuel Production. Virginia Cooperative Extension, 11(1), 442-886. https://doi.org/10.1016/j.nbt.2009.06.630

Keneni, Y. G., \& Marchetti, J. M. (2017). Oil extraction from plant seeds for biodiesel production. AIMS Energy, 5(2), 316-340. https://doi.org/10.3934/energy.2017.2.316

Knothe, G. (2005). the Biodiesel Handbook. In The Biodiesel Handbook: Second Edition. https://doi.org/10.1016/B978-1-893997-62-2.50015-2

Leung, D. Y.C., \& Guo, Y. (2006). Transesterification of neat and used frying oil: 
Optimization for biodiesel production. Fuel Processing Technology, 87(10), 883-890. https://doi.org/10.1016/j.fuproc.2006.06.003

Leung, Dennis Y.C., Wu, X., \& Leung, M. K. H. (2010). A review on biodiesel production using catalyzed transesterification. Applied Energy, 87(4), 1083-1095. https://doi.org/10.1016/j.apenergy.2009.10.006

Lin, L., Cunshan, Z., Vittayapadung, S., Xiangqian, S., \& Mingdong, D. (2011). Opportunities and challenges for biodiesel fuel. Applied Energy, 88(4), 1020-1031. https://doi.org/10.1016/j.apenergy.2010.09.029

Meher, L. C., Vidya Sagar, D., \& Naik, S. N. (2006). Technical aspects of biodiesel production by transesterification - A review. Renewable and Sustainable Energy Reviews, 10(3), 248-268. https://doi.org/10.1016/j.rser.2004.09.002

Meneghetti, S. M. P., Meneghetti, M. R., Serra, T. M., Barbosa, D. C., \& Wolf, C. R. (2007). Biodiesel Production from Vegetable Oil Mixtures : Cottonseed, Soybean, and Castor Oils. 7, 3746-3747.

Moser, B. R. (2008). Influence of blending canola, palm, soybean, and sunflower oil methyl esters on fuel properties of biodiesel. Energy and Fuels, 22(6), 4301-4306. https://doi.org/10.1021/ef800588x

Moser, B. R. (2009). Biodiesel production, properties, and feedstocks. In Vitro Cell.Dev.Biol., 45(March), 229-266. https://doi.org/10.1007/978-1-4419-7145-6

Moser, B. R. (2014). Impact of fatty ester composition on low temperature properties of biodiesel-petroleum diesel blends. Fuel, 115, 500-506. https://doi.org/10.1016/j.fuel.2013.07.075

Murugesan, A., Umarani, C., Chinnusamy, T. R., Krishnan, M., Subramanian, R., \& Neduzchezhain, N. (2009). Production and analysis of bio-diesel from non-edible oils-A review. Renewable and Sustainable Energy Reviews, 13(4), 825-834. https://doi.org/10.1016/j.rser.2008.02.003

Nakpong, P., \& Wootthikanokkhan, S. (2010). Roselle (Hibiscus sabdariffa L.) oil as an alternative feedstock for biodiesel production in Thailand. Fuel, 89(8), 1806-1811. https://doi.org/10.1016/j.fuel.2009.11.040

Nascimento, I. A., Marques, S. S. I., Cabanelas, I. T. D., Pereira, S. A., Druzian, J. I., de Souza, C. O., Vich, D. V., de Carvalho, G. C., \& Nascimento, M. A. (2013). Screening 
Microalgae Strains for Biodiesel Production: Lipid Productivity and Estimation of Fuel Quality Based on Fatty Acids Profiles as Selective Criteria. Bioenergy Research, 6(1), 1-13. https://doi.org/10.1007/s12155-012-9222-2

Nivea, D. L. D. S., Regina, M., Maciel, W., Batistella, C., \& Filho, R. M. (2006). Optimization of Biodiesel Production N IVEA DE L IMA DA S ILVA,* M ARIA R EGINA W OLF M ACIEL ,. Journal of the Food Hygienic Society of Japan, I(December 2013), 1-3. https://doi.org/10.1385/ABAB

Nwabuokei, J. T. N. P. I. (2019). Optimization of Biodiesel Production from Castor Seed Oil Using $\mathrm{NaOH}$ Catalyst. International Journal of Science and Research (IJSR), 8(2), 2046-2050. https://www.ijsr.net/archive/v8i2/ART20195574.pdf

Obianke, M., Muhammad, A., Hassan, L., Aliero, A., \& Liman, M. (2018). Optimization of Reaction Variables in situ Transesterification of Jatropha curcas Oilseed in Biodiesel. Nigerian Journal of Basic and Applied Sciences, 26(2), 102. https://doi.org/10.5455/njbas.301936

Park, Y. W., Chang, P. S., \& Lee, J. H. (2010). Application of triacylglycerol and fatty acid analyses to discriminate blended sesame oil with soybean oil. Food Chemistry, 123(2), 377-383. https://doi.org/10.1016/j.foodchem.2010.04.049

Pradhan, S., Madankar, C. S., Mohanty, P., \& Naik, S. N. (2012). Optimization of reactive extraction of castor seed to produce biodiesel using response surface methodology. Fuel, 97, 848-855. https://doi.org/10.1016/j.fuel.2012.02.052

Qiu, F., Li, Y., Yang, D., Li, X., \& Sun, P. (2011). Biodiesel production from mixed soybean oil and rapeseed oil. Applied Energy, 88(6), 2050-2055. https://doi.org/10.1016/j.apenergy.2010.12.070

Salihu, B. Z., Gana, A. K., \& Apuyor, B. O. (2014). Castor Oil Plant ( Ricinus communis L .): Botany , Ecology and Uses. International Journal of Science and Research, 3(5), $1333-1341$.

Sanli, H., Canakci, M., \& Alptekin, E. (2014). Predicting the higher heating values of waste frying oils as potential biodiesel feedstock. Fuel, 115, 850-854. https://doi.org/10.1016/j.fuel.2013.01.015

Sarin, R., Sharma, M., Sinharay, S., \& Malhotra, R. K. (2007). Jatropha-Palm biodiesel blends: An optimum mix for Asia. Fuel, 86(10-11), 1365-1371. 
https://doi.org/10.1016/j.fuel.2006.11.040

Silitonga, A. S., Masjuki, H. H., Mahlia, T. M. I., Ong, H. C., Chong, W. T., \& Boosroh, M. H. (2013). Overview properties of biodiesel diesel blends from edible and non-edible feedstock. Renewable and Sustainable Energy Reviews, 22, 346-360. https://doi.org/10.1016/j.rser.2013.01.055

Singh, S. P., \& Singh, D. (2010). Biodiesel production through the use of different sources and characterization of oils and their esters as the substitute of diesel: A review. Renewable and Sustainable Energy Reviews, 14(1), 200-216. https://doi.org/10.1016/j.rser.2009.07.017

Srivastava, A., \& Prasad, R. (2000). Triglycerides-based diesel fuels. Renewable \& Sustainable Energy Reviews, 4(2), 111-133. https://doi.org/10.1016/S13640321(99)00013-1

Tabatabaei, M., Karimi, K., Horváth, I. S., \& Kumar, R. (2015). Recent trends in biodiesel production. Biofuel Research Journal, 2(3), 258-267. https://doi.org/10.18331/BRJ2015.2.3.4

Taghizade, Z. (2016). Determination of biodiesel quality parameters for optimization of production process conditions. 23.

Wang, P. S., Tat, M. E., \& Gerpen, J. Van. (2005). The Production of Fatty Acid Isopropyl Esters and Their Use as a Diesel Engine Fuel. 82(11).

Yusuf, A. ., Mamza, P. A. ., Ahmed, A, S., \& Agunwa, U. (2015). Extraction And Characterization Of Castor Seed Oil. The Internet Journal of Nutrition and Wellness, $8(2)$. https://doi.org/10.5580/147f

Zhang, Y., Dubé, M. A., McLean, D. D., \& Kates, M. (2003). Biodiesel production from waste cooking oil: 1. Process design and technological assessment. Bioresource Technology, 89(1), 1-16. https://doi.org/10.1016/S0960-8524(03)00040-3 